Forthcoming in the inaugural issue of Journal of Chinese Economic and Business Studies

\title{
China's Economic Growth After WTO Membership
}

\author{
Jeffrey D. Sachs \\ Earth Institute, Columbia University \\ 405 Low Library, MC 4335 \\ 535 West 116th Street \\ New York, NY 10027 \\ sachs@columbia.edu \\ and \\ Wing Thye Woo \\ Economics Department, University of California \\ One Shields Avenue \\ Davis, CA 95616 \\ wtwoo@ucdavis.edu
}

September 2002

\begin{abstract}
$\underline{\text { Abstract }}$
We assess the prospects of China's future growth performance in two steps. The first step is to project the potential growth path by determining whether past successes were generated by economic experimentation that produced non-capitalist institutional innovations (e.g. incentive contracts to state enterprises, profit-oriented supervision by state industrial bureaux, collectively-owned rural enterprises), or by institutional convergence toward the advanced WTO economies like France, Japan and the United States - two interpretations known respectively as the experimentalist school and the convergence school. Because WTO membership would harmonise China's economic institutions with those of capitalist economies and reduce the scope for experimentation, the experimentalist school would project a lower potential growth path than the convergence school. The fact that China has sought WTO membership voluntarily and with great tenacity is recognition of the correctness of the convergence interpretation.

The second step in assessing China's growth prospects is to project the extent and duration that actual growth would deviate from potential growth. We assess the possibility of a WTO-induced macroeconomic shock that would generate such great political turmoil that prolonged economic stagnation would result. This macroeconomic shock could take two forms: a flood of imports that would cause widespread unemployment; and the entry of foreign banks that would bankrupt the domestic banks, and hence shut down the national credit system, crippling production economy-wide. Our main conclusions are that the government has the technical means to avert such this WTO-induced macroeconomic shock, and that the real threat to macroeconomic stability is China's weak fiscal position.
\end{abstract}

JEL code: H30, O11, O40, O53, P20, P22, P26, P31, P52

Keywords: Fragile financial system, fiscal crisis, Convergence school, Experimentalist school

We are grateful to Bao Shuming, Sylvie Démurger, Guy Shaojia Liu, Fan Gang, Hai Wen, Lu Ding, Wang Xiaolu, and Xiao Geng for many insightful conversations on China's economy; and to Huang Yiping and Yang Xiaokai for allowing us to draw upon the results from our joint research. This paper is part of the "Property Rights and China's Enterprise Reform" project (HKU7167/98H) supported by the Research Grant Council of Hong Kong. 
19 September, 2002

\section{China's Economic Growth After WTO Membership}

Jeffrey D. Sachs and Wing Thye Woo

Columbia University and University of California at Davis

\section{$\underline{\text { Section 1: China's Economy History at a New Juncture }}$}

\section{1: Two Interpretations of Recent Economic History}

China is now in the midst of three historic economic transformations. It is simultaneously undergoing economic transition from a planned economy to a market economy, economic development from a largely subsistence peasant economy to an industrialized economy with a modern service sector, and economic globalization from autarky to an important node within the global production network. Roughly speaking, the process of economic transition was unleashed in 1979 when the central government turned a blind eye to the decollectivization of agriculture, and allowed free agricultural markets. The process of economic development began in earnest in 1984 when the government sanctioned the establishment of non-state industrial enterprises in the rural areas. Finally, the process of economic globalization was credibly legitimized in 1984 when free trade and liberal foreign investment policies were extended from the four special economic zones established in 1979-80 to fourteen other coastal cities.

The rest, as they say, is history. By 1981, at least 67 percent of China's workforce -- the proportion employed in the primary sector -- had left the planned economy. This great amount of liberalisation in two years really amounted to an economic revolution, a revolution that finally 
gave land and brought unprecedented prosperity to the peasants. ${ }^{1}$ Beginning in 1984 , non-state industrial enterprises (particularly the collectively-owned township and village enterprise, TVEs) metastasized so quickly throughout the coastal provinces that, by 1989 , state-owned enterprises (SOEs) produced only 56 percent of gross industrial output, down from 73 percent in $1983 .^{2}$ The similarly rapid internationalisation of the economies of the coastal provinces raised China's exports from US\$22 billion in 1983 to US\$53 billion in 1989, and foreign direct investment into China from US\$0.6 billion in 1983 to US\$34 billion in 1989. The outcome from these three processes of economic transformation was a stunning average annual GDP growth rate of 9.5 percent in the 1979-2002 period.

The preceding account is certainly impressive history, but it is not uncontested history. There has been much debate among China-watchers over the basic interpretations of the most important features of China's success. Among the key questions in the debate are:

- What is the fundamental driving force behind China's high sustained growth rate that makes its experience so different from those of Eastern Europe and the former Soviet Union (EEFSU)?

- How successful has China's SOE reform really been? Are product competition, incentive contracts, and profit-oriented supervision by industrial bureaux the sufficient ingredients to generate sustained improvement in enterprise efficiency?

The contentiousness that has marked the interpretation of China's recent economic history is quite aptly captured in the titles of two books on the subject. Justin Lin, Fang Cai and Zhou Li (1996) wrote of The China Miracle, while Ross Garnaut and Yiping Huang (2001) informed us

\footnotetext{
${ }^{1}$ See Zhou (1996) and Zweig (1997).

${ }^{2}$ Ratios are different depending on source and base year. The ones above were calculated from State Statistic Bureau, Comprehensive Statistical Data and Materials on 50 Years of New China, 1999, using 1995 prices. Ratios calculated from China Statistical Yearbook 2000 using 1999 prices would yield 63 percent in 1989 and 83 in 1983.
} 
about Growth Without Miracles. So many conflicting answers have been proposed by Chinawatchers, especially on the TVE phenomenon, that it is almost like the old story of a group of blind scholars pawing an elephant, with each confidently concluding what the whole elephant resembles on the basis of the specific part that she was foundling.

The answers to the above two questions are of more than academic interest. They also provide the correct way to think about China's growth after WTO membership. Specifically, China's future growth performance depends crucially on whether past successes were the result of its economic experimentation that produced non-capitalist institutional innovations that were optimally suited to China's particular economic circumstances, or the result of its institutional convergence and integration with the advanced WTO economies like France, Japan and the United States. In Sachs and Woo (2000a), we labeled these two competing interpretations of China's post-1978 economic history - institutional innovations versus institutional convergence - the Experimentalist School and the Convergence School respectively.

On the one hand, the experimentalist view holds that dual-track pricing was (and is?) intrinsically superior to complete price liberalization, and that improvement in SOE efficiency requires only enhanced product competition and not diversification of ownership forms. Gradual, piecemeal reform is seen to be superior to fast, comprehensive reform because economic experimentation on different degrees of price flexibility, different types of SOE contracts, and different forms of ownership structures are necessary in order to discover the institutional features that are optimal for China's specific economic conditions. Gradual reform is viewed as the byproduct of the time-consuming processes of undertaking economic experimentation, of verifying the initial results in other locations, and of propagating the new institutional innovations nationally. Considerable sympathy was given to the interpretation of 
hybrid institutions (such as township and village enterprises, or TVEs), as reflecting distinctive Chinese cultural patterns, for example in Weitzman and Xu's (1994) well-known explanation for why most of China's rural enterprises were collectively-owned, when almost all rural enterprises elsewhere in the world, e.g. in Indonesia and Taiwan, are privately-owned. They attributed the Chinese exception to the unusually strong sense of brotherhood, gemenxing, among Chinese. ${ }^{3}$

On the other hand, the convergence school believes that the experimentalists have made economic virtues out of political necessities in China's uneven and drawn-out reform process. We, and many other scholars in the same vein, have suggested that dual-track pricing was the product of political constraints and not of economic optimization, and hence was non-viable beyond the short-run. We have deemed that privatization of the bulk of the SOEs is both inevitable and desirable, though we have worried and continue to worry that it must be carried out transparently and honestly, lest the corruption that characterized Russian privatization undermine the very economic goals that privatization is designed to support. In essence, we have argued that the institutional infrastructure that China needs at this point to move from a low-income country to an upper-middle income country can be gotten mainly by adopting the best international practices in the different spheres, and then modifying them as experience accumulates (in China and elsewhere in the world). The East Asian experience, not surprisingly, will be the most relevant, since that is the best case of "catching-up" industrialization that the world offers. Even there, however, changes in international markets over time suggest that blind adherence to some earlier formula will not succeed in the present and future context.

\footnotetext{
${ }^{3}$ Another example is Naughton (1994) who interpreted the TVE ownership structure as a good adaptation to market failures caused by China's underdeveloped markets for factors of production: "Banks are ill-equipped in the early stages of transition to process small-scale lending applications and assess risks. Local government ownership in China played a crucial role in financial intermediation. Local governments could better assess the risks of start-up businesses under their control ... and serve as guarantors of loans to individual TVEs."
} 
The two points of view are themselves converging to some extent, especially under the glare of real events. On the one side, almost all of the experimentalists now concede that China will become a "normal" capitalist economy, with private ownership, the corporate form of organization in large organizations, and adherence to international rules of the game in trade and finance. The accession to the WTO has put "facts on the ground," as it were. At the same time, the convergence school does not argue for a "textbook" model of free enterprise, but rather for using the practical experience and global rules of the game as the key guideposts. Moreover, since there is considerable variation in actual practices among the U.S., Western Europe, and Japan, not to mention smaller economies such as Korea and Singapore, there is no model worthy of blind adherence. In many critical areas, moreover - social policy, social insurance, science and technology policy, regional development - some experimentation is surely needed, since even the market economies have settled on no clear recipes.

Even though views are converging, there are still differences in emphasis, and therefore in forecasts about the future. The experimentalists tend toward pessimism regarding China's accession to the WTO, since this will force even more institutional harmonization, while the convergence school is inclined toward optimism for the same reason: WTO membership will require that China further harmonize its key economic institutions with those of the leading market economies. ${ }^{4}$ The experimentalists are understandably uneasy about the external constraints over economic experimentation, but the convergence school believes that China will continue to benefit from the adoption of "international best practices." Both sides agree, however, that WTO rules should be interpreted not only for China, but for all developing countries, in a manner that supports economic "catching up."

\footnotetext{
${ }^{4}$ Of course, WTO does not specify a single institutional form, e.g. bank financing versus stock market financing firms, but there are some key common features like dominance of private ownership and equal legal protection for state capital, domestic private capital, and foreign capital.
} 


\section{2: WTO-Induced Costs}

Of course, an assessment of China's growth after WTO membership requires more than a correct understanding of the economic mechanisms responsible for past successes. To be useful, the assessment must also address seriously the frequently-encountered prediction that the WTO process would generate such large political turmoil that there would be economic stagnation for an extended period. The most-discussed mechanism through which WTO would create a political meltdown is a macroeconomic shock. The macroeconomic shock from WTO membership could take two forms. First, WTO membership might promote a flood of imports that would cause widespread unemployment in the urban and rural areas, and hence provoke the social unrest that would bring about the macroeconomic collapse. Second, the entry of foreign banks could divert deposits from the already bankrupt domestic banks, and the resulting shutdown of the credit system would disrupt production economy-wide.

In the ominous words of Gordon Chang (author of The Coming Collapse of China),

WTO accession "will shake China to its foundations". ${ }^{5}$

"In 1998, there were 60,000 protests ... [and in 1999], there were 100,000. Anecdotally, we know at least that demonstrations last year grew bigger ... But the most significant aspect of the recent demonstrations is not their increasing size. It is that these days, barehanded peasants and workers are desperate enough to do battle with armed state security forces. That tells us volumes about the state of China today.

"... China's imminent accession to the World Trade Organization can only aggravate the problem of instability, because membership will limit Beijing's ability to postpone solutions ... [Imports] will flood the country. And that means uncompetitive state-owned enterprises will fail in even greater numbers than they do today... And in the countryside, expect China's peasants to be hit even harder than the urban proletariat, as efficient foreign agribusiness penetrates Chinese markets.

\footnotetext{
${ }^{5}$ Chang (2001), pp.xviii.
} 
"... Accession will knock one or two percentage points off increases in GDP ... [and] China is at the point where the loss of even a percentage point of growth would have a disproportionate impact on urban workers and the peasantry ... [The fact is that] many Chinese today are still hungry, angry and, worst of all, desperate. That desperation will escalate as the country settles into the WTO." ${ }^{6}$

"The People's Bank of China, the country's central bank, says that about $30 \%$ of the loans of the four biggest banks are nonperforming, but that assessment is based on accounting with Chinese characteristics. Foreign observers put the figure closer to $50 \%$, and some even say higher.

... But in less than five years, foreign banks, in accordance with China's World Trade Organization commitments, will be able to accept local-currency deposits from Chinese citizens. If foreign institutions are able to divert just a little liquidity away from the Big Four, there will be a banking crisis of historic proportions. Beijing's leaders will try to avoid tragedy, but they might not succeed. For one thing, they don't have enough money." ${ }^{7}$

The rest of this paper assesses such concerns. We start by reviewing the recent growth experience in China, to give a basis for our "convergence" interpretation, which after all, are the basis for our optimism. These topics are covered in Section 2, which examines why the output response to marketisation was so different in China and EEFSU, and in Section 3, which assesses the degree of success in reforming China's SOE sector. In both sections, we arrive at the conclusion that WTO-type reforms will be beneficial for China's continuing economic development. In Section 4 we turn to the future, to investigate the probability of WTO-induced macroeconomic shocks, and the resilience of China's economy to such shocks. We explore in this section the policies that the Chinese Government can implement to counter negative developments from WTO membership.

\footnotetext{
${ }^{6}$ Gordon G. Chang, "The Shahs of Beijing," Far Eastern Economic Review, September 13, 2001.

${ }^{7}$ Gordon G. Chang, "Don't Bank on China," Far Eastern Economic Review, July 18, 2002.
} 


\section{Section 2: Output Response to Marketization: Why is China Different?}

The standard interpretation as to marketisation depressed output in EEFSU and raised output in China is that the two regions implemented drastically different marketisation policies. EEFSU enacted fast, comprehensive ("big bang") reforms, while China initiated piecemeal, partial reforms. Speed is widely alleged to be the culprit. ${ }^{8}$

"Big bang transitions inevitably involve large short-run adjustment costs, generally including discontinuous changes in the price system, and sharp increases in unemployment." (Naughton, 1995a)

Justin Lin, Fang Cai, and Zhou Li (1996) took the flip side of Naughton's assertion to mean that gradual reform inevitably led to output growth. They presented production possibility frontiers (p-p-f) as in Figures 1 and 2 to show the respective consequences of big bang reform and gradual reform on an initially inefficient economy (i.e. initially operating at point B which is inside the p-p-f) that had an overly large heavy industrial sector. The important claim is that gradual reform not only unambiguously moves the economy toward the $\mathrm{p}-\mathrm{p}-\mathrm{f}$, it also moves the p-p-f outward.

Neither Naughton (1995a) nor Lin, Cai and Li (1996) spelled out explicitly the mechanism through which a partial reform was necessarily Pareto-improving (or output enhancing). This task was undertaken by Lau, Qian and Roland (2000), and was discussed critically in Woo (2001). The basic idea is that partial reform, specifically two-track pricing, allowed the growth and development of China's light industry while maintaining privileged

\footnotetext{
${ }^{8}$ Peter Nolan and Robert Ash (1995) went one step further to claim that both speed and the nature of the state were the primary determinants: “... the Soviet failure stems primarily from the wholehearted embrace of the "transition orthodoxy" policies of political reform (perestroika and glasnost) and subsequent economic change ("shock therapy") ... China's reform success stems primarily from its refusal to implement the "transition orthodoxy" policies ... Meanwhile, the maintenance [in China] of an authoritarian political system allowed the gradual development of market forces, helped facilitate fiscal stability, provided a stable environment for large-scale foreign capital flows and provided a means of intervention in areas of market failure."
} 
access by the old heavy-industry SOE to cheap inputs, thereby preventing undue layoffs in the old SOE sector as a result of market liberalization. The old heavy industrial sector is cushioned so that it shrinks gradually, but no faster than the growth of the new light-industrial sector. The important point is that the old state sector is allowed to shrink, but only in line with growth of the new economy. (Lau, Qian and Roland, 2002, actually claimed that the two-track pricing system induced employers to adopt a contractual scheme where labor is transferred from the old SOEs to the new light-industrial sector).

It is not a bad argument in theory, but it is, unfortunately, also not a good summary description of China's actual growth process. In fact, the key prediction in Lau, Qian and Roland of a slow and voluntary contraction in heavy industrial output upon marketization of the economy is contradicted by the data in Table 1, which shows that the output of both the light and heavy industrial sectors went up every year following the introduction of the dual-track pricing in 1985. Clearly, we need an explanation other than gradual reform and two-track pricing to explain why China grew so fast upon marketization, even as the old SOE sector continued to expand! It was not, to be sure, to promote the gradual decline of the old state sector.

Table 1 shows two interesting facts that suggest an alternative explanation for what really happened in China. First, output from industrial SOEs increased every year in the reform era, but the state sector's share of total industrial output declined secularly from 78 percent in 1978 to 28 percent in 1998. This means that the bulk of the increase in industrial output came from the nonstate sector. Hence, credit for the fast growth of industrial output should be given to the legalization of the non-state ownership system in the industrial sector in 1984, and not to the two-track pricing introduced in the same year. 
Second, and perhaps most important, the non-state sector did not grow by obtaining their labor from the state sector, the key mechanism behind the Lau, Qian and Roland's assertion of "gain without pain" through gradual reform. State employment was 17.9 percent of the labor force in 1984 (the eve of the introduction of dual-track pricing in the industrial sector) and it rose to 18.3 percent in 1989 (the eve of the replacement of dual-track pricing with almost complete price decontrol). The state sector in 1989 employed 14.7 million workers more than in 1984, and 26.6 million more than in 1978. In employment terms, China was certainly not growing out of the plan either in absolute or in relative terms.

The labor that fuelled the fast expansion of the non-state industrial sector came out from agriculture, a sector that is generally not understood by the experimentalist school as absolutely crucial for rapid industrialization after 1984. The deus ex machina of China's growth is evident from the decline of employment in the primary sector from 71 percent of the workforce in 1978 to 50 percent in $1998 .{ }^{9}$ China's marketization and internationalization policies had initiated the positive sum process of economic development, moving China away from a subsistence peasant economy and causing agriculture to drop from 41 percent of GDP in 1978 to 18 percent in 1998. ${ }^{10}$ China's growth has been built on surplus rural labor, not the gradualism of industrial reform.

Russia, on the other hand, was an over-industrialised economy (particularly in the heavy industries) in 1989 with a small agricultural sector, and essentially no peasant sector available to provide labor to industry. Industrial output accounted for 49 percent of Russia's GDP in 1988

\footnotetext{
${ }^{9}$ This decline in agricultural employment is likely to be understated because it does not take illegal migration into account.

${ }^{10}$ Ratios were calculated in 1995 prices.
} 
compared to 24 percent of U.S. GDP in $1986 .{ }^{11}$ Given the relatively small proportion of labor in Russian agriculture compared to China, 19 percent versus 71 percent, a substantial amount of the labor needed for the growth of new light industries and new service activities had to come from the heavy industrial sector. The sharp shrinkage of Russia's heavy industries was necessary in order to release the labor put there by the central plan. ${ }^{12}$ This need for a shrinkage of heavy industry was dramatically compounded by the collapse in output of energy as well, which was literally and figuratively the fuel of so much of Russia's heavy industrialization. In essence, Russia's heavy industry - the "commanding heights of the old economy - was doomed to decline, in a way that China's heavy industrial sector was not. The salient point is that the marketization of the over-industrialised Russian economy triggered a much more fractious struggle, since the decline of one sector (heavy industry) was almost a predicate for the rise of another (light industry and modern services).

The importance of how existing structural conditions shape the output response to marketisation is heuristically captured in Figure 3, which shows a three-dimensional production possibility frontier of output from agriculture, light industry and services, and heavy industry. Point B on plane NOP denotes the production mix of a developed private market economy that is integrated into the international division of labor. Point $\mathrm{A}$, which is also on plane NOP, represents Russia on the eve of its marketisation in 1992, and point C on plane KLM represents China in 1978. The difference between plane NOP and plane KLM is that the former represents economies that are more advanced in their industrialisation and urbanisation. China's twin

\footnotetext{
${ }^{11}$ In 1988, the Soviet Union produced 15 times more crude steel per dollar of GDP than the United States, and 8 times more than West Germany and Japan. The Soviet Union also produced five times more refined copper per dollar of GDP than the United States, West Germany and Japan.

${ }^{12}$ Sachs and Woo (1994) pointed out that there had to be a big cut in welfare subsidies provide by the government through the state enterprises before workers could be induced to seek employment in the new non-subsidized private sector.
} 
processes of economic transition and economic development moved it from point $\mathrm{C}$ toward point $\mathrm{B}$, while Russia's transition process moved it from point A toward point $\mathrm{B} .^{13}$

The crucial point is that China's reform was able to unleash sustained growth because the marginal value product of labor (MVPL) was very low in agriculture compared to the other sectors. According to Chow (1993), the marginal value product ${ }^{14}$ of labor in China in 1978 was 63 yuan in agriculture, 1027 yuan in industry, 452 yuan in construction, 739 yuan in transportation and 1809 yuan in commerce. This is the true source of the Pareto-improving outcome in China's economic reform, not the dual pricing system. ${ }^{15}$ And the existence of surplus labor was actually multiplied in the early years of reform, when the return to household farm plots raised food productivity and left an even larger number of agricultural workers without effective use at the farm.

Suppose that China had in fact pursued more rapid liberalization of the economy, including a harder budget constraint on state enterprises and a faster unification of product markets and the market for foreign exchange. How much larger would have been the dislocations in the economy? While we cannot answer this crucial question with any precision, it is instructive to look next door at the case of Vietnam. During 1985-88, Vietnam implemented a gradual reform strategy that did not address serious macroeconomic imbalances. The program failed: inflation and import of rice accelerated while growth performance remained unchanged.

\footnotetext{
${ }^{13}$ Figure 3 is from Woo (2001). In a sense, Figure 3 subsumes Figure 1 and Figure 2. The plane K'OM' is the original pp-p-f in Figure 2, and the plane NOP is both the p-p-f in Figure 1 as well as the new p-p-f in Figure 2. ${ }^{14}$ Measured in 1952 prices.

${ }^{15}$ Woo (2001) has argued that dual-track pricing was an unsustainable economic mechanism, not only from the management viewpoint of extreme difficulties in administration, but also from the political viewpoint of maintaining the cohesion of the ruling coalition. The plan track for inputs conferred instant profits upon the favored purchaser upon reselling quota inputs in the free market. The resulting outcry over the "middleman" role of many children of top leaders led Hu Yaobang, then head of the Communist Party of China (CPC), to arrest the children of several top conservative leaders. This crackdown aggravated the infighting inside the ruling coalition, which contributed to the dismissal of Hu Yaobang as head of the CPC. The choice facing the CPC elite was to either maintain the political coalition or maintain the dual track price system. Political reality is the reason why the plan track was ended quickly in the 1990-91 period when the conservatives were in charge even though this action was not Pareto-improving and against their ideological precepts.
} 
In 1989, Vietnam enacted an Eastern-European style "big bang," including across-the-board price liberalization, a 450 percent devaluation to unify the exchange market, and a tight credit policy. The collective farms were returned to family farms with long-term leases. Growth accelerated, inflation ended, agricultural productivity soared (turning Vietnam into a rice exporter in 1989), and small, non-state enterprises proliferated, Riedel and Comer (1996). The "big bang" did not cause an output decline in Vietnam as in Eastern Europe. The difference in outcome, as in China, lies in Vietnam's economic structure in 1989, in which 77 percent of the labor force was engaged in agricultural activities. As an overwhelmingly agricultural economy, Vietnam enjoyed the same gains as China from liberalization of agriculture, and the flow of peasants to the non-agricultural sector. Strong market-oriented reforms (macroeconomic stabilization and liberalization), not gradualism per se, tended to accelerate this shift. ${ }^{16}$

The primary importance of the transition from agriculture in explaining China's post1978 growth is also confirmed in the independent growth accounting exercises by Woo (1998) and World Bank (1996) who partitioned total factor productivity (TFP) growth into (a) labor reallocation effect, and (b) net TFP growth. Their findings summarised in Table 2 generally show little meaningful differences, and their estimates of the growth contribution of labor reallocation away from agriculture are in close agreement, 1.1 to 1.3 percentage points. The reallocation of labor from agriculture accounted for more than half of the observed TFP growth in 1985-1994, reflecting the great movement toward higher-productivity jobs in the industry and service sectors. The high labor reallocation effect in China is not unprecedented. It is in line with Ohkawa and Rosovsky's (1973, pp.116) estimates of the average annual contribution to Japan's aggregate output growth from the reallocation of agricultural labor starting in the mid-

\footnotetext{
${ }^{16}$ Laos followed Vietnam's lead in economic reform -- gradual reform in 1985-88 and big bang reform in 1989 -and had the same output response as in Vietnam.
} 
1950s when the trend growth rate accelerated as Japan increased it's integration into the global economy: 1.46 percentage points in 1952-55, and 1.07 percentage points in 1961-65.

Finally, it should be noted that gradualism had been tried in Eastern Europe and the Soviet Union several times (e.g. Kadar's Hungary, Jaruzelski's Poland and Gorbachev's Russia), and it failed each time. The liberalization there unleashed financial destabilization, without promoting the growth of a new private sector because subsidies to the SOEs were not cut. Careful econometric studies by Aslund, Boone and Johnson (1996) and Berg, Borensztein, Sahay and Zettelmeyer (1999) of EEFSU countries found that the magnitude of a country's collapse in output was unrelated to the speed and comprehensiveness of the reform package, and that recovery began sooner and private sector development was more dynamic in the "big bang" countries. $^{17}$

\section{Section 3: SOE Response to Reform: Is China Different?}

The common official reaction in China to clear signs of waste and inefficiency in the industrial sector had been to instruct the supervising ministry to tighten its oversight of the individual enterprises. It was therefore a startling departure when the party secretary of Sichuan, Zhao Ziyang, sought to improve SOE performance in October 1978 by devolving limited operational autonomy to a small number of SOEs. The fact that Zhao Ziyang's actions occurred before the landmark Third Plenary Session of the Eleventh Central Committee in December

\footnotetext{
${ }^{17}$ We had noted earlier the Nolan and Ash (1995) hypothesis that China's successes had come from the slowness and unorthodoxy of its reform as well as from the authoritarian nature of the regime. These correlationships among growth, gradual reform, and authoritarian state was also recognised by a former high ranking Soviet planning official, Yevgenii Yasin, who, however, gave a different causal ordering to them. In his interpretation of the evidence, only an authoritarian state could have made gradual reform work: "a gradual transition to a market economy [would have required] ... a less radical and painful departure from socialist ideals. The secret police and censorship would perpetuate the old ideological cocoon, within which a new economic system would be developing like a butterfly... The last chance was lost in 1989, when Gorbachev's political reform removed the Communist Party from power. Afterwards, events unfolded spontaneously, no longer under the control of the government or the Party.” (Ellman and Kontorovich, 1998, pp.169)
} 
1978 (when economic reconstruction replaced ideological work as the primary objective of the Communist Party of China, CPC) may no doubt indicate the boldness of Zhao as a reformer. It may, more importantly, also reveal that China's industries were so inefficient at the end of the decade-long Cultural Revolution that the $\mathrm{CPC}$ was receptive to some unorthodox reform measures. Zhao Ziyang's initiative was subsequently adopted haphazardly in several other locations, and widened incrementally as the ideological climate evolved.

The triumph of the economic reformers in November 1978 led to the replacement of the agricultural communes with the contract responsibility system, which gave rural households 15year leases on their land. The resulting jump in agriculture production in 1979-83 convinced China's leadership to extend the contract responsibility system to the industrial sector in $1984{ }^{18}$ What might have also helped to make decentralisation reforms acceptable was that they had already been implemented in various degrees in Eastern Europe, the best-known case being Hungary. Managers began receiving in piece-meal fashion the rights to make decisions about bonuses, how and what to produce, pricing, marketing, and investment. In parallel with this expansion of managerial autonomy, there was steady decontrol of prices and reduction in state orders delivered at plan prices.

Good news on the SOE front soon appeared in western economic journals, announcing that China had succeeded in finding the kind of SOE contracts and the type of bureaucratic monitoring that work. Jefferson, Rawski and Zheng (1992) found that annual TFP growth averaged 2.4 percent in the 1980-88 period; and Jefferson, Rawski and Zheng (1996) revised it to 2.5 percent for the 1980-92 period. Groves, Hong, McMillan and Naughton (1995a) estimated annual TFP growth in the 1980-89 period to range from 2.3 percent in the food products sector to 7.9 percent in the electronic sector. Groves, Hong, McMillan and Naughton (1995b) concluded

\footnotetext{
${ }^{18}$ Zhao Ziyang had become the prime minister in 1980.
} 
that the industrial bureaux were actively rewarding effective managers and removing incompetent ones. These results led to the assertion by some, particularly among the experimentalist school, that ownership reform (i.e. privatisation) was not important to improving SOE performance, the active ingredients were increased product competition, well-designed incentive contracts, and better monitoring by the industrial bureaux. ${ }^{19}$

It is interesting to note, however, that the most influential policy-advising group in China during the 1984-88 period, the China Economic System Reform Research Institute (Tigaisuo), had released a field study in 1986 that found that the decentralisation measures had given the SOEs the room to over-compensate their workers and managers, and to clamor unceasingly for new bank loans in order invest recklessly. ${ }^{20}$ To a scholar of Eastern European economies, this behavior is not new. It reflects the consequences of the soft-budget constraint ${ }^{21}$ where an SOE could employ book-keeping subterfuges to privatise the profits of a successful investment, and socialise the losses of a failed investment by getting a subsidy from a socialist government that is committed to zero unemployment. If the Chinese managers were also similar their Eastern European cousins in that they prefer lobbying hard for new bank loans and fiscal subsidies to working hard to seek productivity increases, then there could not have been sustained growth in productivity gains as claimed by some fans of the SOEs.

By 1992, the Tigaisuo view of failed SOE reform had became the dominant view in China. The disappointment caused a fundamental change in the official philosophy on SOE

\footnotetext{
${ }^{19}$ Under the section heading of "Privatization is not crucial; competition is," McMillan and Naughton (1992) wrote: "China proves .. that it is possible for state-owned firms to be induced to improve productivity that falls short of privatization." In Naughton's (1995b) reading of the evidence: "Studies of state enterprise productivity have shown gains in productivity and output, sufficient to maintain overall economic momentum and dynamism." (emphasis added).

${ }^{20}$ This report has been published in English as Reynolds (1987).

${ }^{21}$ A term coined by the Hungarian economist Janos Kornai (1980).
} 
reform. In November 1993, the Central Committee of CPC identified the clarification property rights to be the key to enterprise reform, and declared that:

Large and medium-sized State-owned enterprises are the mainstay of the national economy; ... [for them,] it is useful to experiment with the corporate system ... As for the small State-owned enterprises, the management of some can be contracted out or leased; others can be shifted to the partnership system in the form of stock sharing, or sold to collectives and individuals. ${ }^{22}$

The Tigaisuo assessment of SOE was soon confirmed by a host of articles in western economic journals that found negative negative or temporary TFP improvments. Huang and Meng (1995) found the annual TFP growth rate to be negative 5 percent in the $1986-90$ period, and the number of skilled workers in SOEs to be excessive. Woo, Hai, Jin and Fan (1994) found TFP growth to be zero in the 1984-88 period; and Bouin (1998) found annual TFP growth to range from -0.7 to 0.2 percent in the $1989-93$ period.

$\mathrm{Wu}$ and $\mathrm{Wu}$ (1994) found TFP to increase in the 1979-84 period but to be stagnant in the 1985-92 period. Perkins, Zheng and Cao (1993) established that there were significant regional variations in TFP growth: for the Special Economic Zone of Xiamen, the TFP index went from 100 in 1980 to 139 in 1985 and then to 131 in 1988; for Shanghai, it went from 100 in 1985 to 99 in 1988; and, for Beijing, it went from steadily down from 100 in 1983 to 74 in 1988. The overall national picture was that the TFP index rose from 100 in 1981 to 104 in 1985 and then declined steadily to 81 in 1989 . Using samples for medium and large state-owned construction enterprises, Parker (1995 and 1997) found that annual TFP growth averaged 1 percent in the 1985-1991 period but declined significantly over time.

It appears that the Oskar Lange-type market socialism reforms in China, just as in Eastern Europe earlier, could at best yield temporary TFP growth. Given the gross inefficiency in the

\footnotetext{
22 "Decision of the CPC Central Committee on issues concerning the establishment of a socialist market economic structure," China Daily, Supplement, November 17, 1993.
} 
SOE sector in early 1980s, it did not require much talent or effort by the managers to improve the productivity of SOEs. The innovative SOE contracts and the active personnel management by the industrial bureaux could not, however, provide strong enough incentives to sustain efficiency growth over time. Some truly fundamental active ingredients were obviously missing in the decentralisation problems. ${ }^{23}$

In his response to the emerging negative verdict on the SOE sector, Barry Naughton (1995a) attributed it to the Chinese government's ignorance about technical economics, and to the right-wing dogmatism of some western academic researchers.

Focusing on profitability, [state bureaucrats] see the erosion in state sector profits as a profound crisis of the state sector. Without good measures of total factor productivity, they conclude that state sector performance is deteriorating. Foreign observers, hearing the cries of alarm from the state planners, shake their heads knowingly as they perceive still further evidence that state ownership is intrinsically inefficient. Neither party sees that the difficulties are the result of an ultimately beneficial transition to a different type of economy, and are entirely compatible with gradually improving efficiency.

Later on, when the economic inefficiency of the SOE sector became glaringly obvious to most observers, Naughton (1995b) identified a break in enterprise efficiency improvement in 1989-90. ${ }^{24}$ To him, this breakdown in efficiency growth was not due to any inherent limitation of the contract responsibility system, the breakdown was caused by the Tiananmen incident of June 1989.

\footnotetext{
${ }^{23}$ See Huang, Woo, and Duncan (1999) for an account of the failure of SOE reform.

${ }^{24}$ There is of course still controversy over the productivity performance of the SOEs. For example, the debate between Woo, Hai, Jin and Fan (WHJF) and Jefferson, Rawski and Zheng (JRZ) continues. It started when WHJF (1994) found that the implicit value added deflator (VAD) constructed from the nominal value added series and the real value added series in JRZ (1992) declined secularly in the 1980-86 period in contrast to the secularly rising consumer price index (CPI). (This phenomenon of declining VAD also applies to Groves, Hong, McMillan and Naughton, 1994, 1995a, and 1995b). WHJF attributed regarded this internationally unprecedented phenomenon to JRZ's overstatement of gross output and understatement of the intermediate inputs used in production. JRZ (1996) defended their deflators for gross output and intermediate inputs, and attributed the declining VAD to the unusual production structure of China's manufacturing sector. However, Woo (2001) showed that this claim to be untrue when the structure was calculated from the input-output table. Woo suggested that JRZ's finding was the result of comparing U.S. and Chinese value added data that were constructed from different definitions.
} 
"[After the Tiananmen incident] government officials renewed their interference with enterprise decision-making ... New regulations were issued on permissible bonuses and income differentials. Thus bureaucrats destroyed the credibility of their pledge to provide increased autonomy to enterprises and their managers. In the atmosphere of political crisis following Tiananmen, governments reneged on their promises, and restricted enterprise autonomy.

... The gradual, controlled granting of autonomy and incentives to SOEs, so characteristic of the 1980s, is no longer feasible. The government is incapable of credibly committing to a new set of long-run incentive contracts."

In any case, the government had by 1993 decided to clarify the property rights of SOEs in order to salvage its SOE reform program. The CPC publicly committed itself in July 1997 to convert most of the SOEs to publicly traded shareholding corporations. This convergence to a form of industrial organisation that originated in capitalist economies was possibly motivated more by a concern over the soaring loss of the SOE sector than by its continued inefficiency. The losses at the beginning of the 1990s were so severe that it was common for even government officials to say that "one-third of the country's state enterprises were in the red, and another onethird were in a latent loss-making state. ${ }^{25}$ This financial situation has worsened over time. A national audit of 100 SOEs in 1999 found that eighty-one falsified their books, and sixty-nine reported profits that did not exist; and an audit of the Industrial and Commercial Bank of China and the China Construction Bank found that accounting abuses involving RMB 400 billion, of which RMB 200 billion was overstatement of assets. ${ }^{26}$

The difference between the experimentalist and convergence interpretations of the sharp collapse in SOE profit rates lies in the different weights that they put on each of the three factors that the literature has identified: increased competition from the non-state enterprises, failure of the SOEs to improve their efficiency, and over-compensation of SOE personnel. The

\footnotetext{
${ }^{25}$ Lin, Cai and Li (1996, pp. 215).

26 "China: Finance ministry reveals widespread accounting fraud,” Financial Times, December 24, 1999. In January 2000, auditors in Hebei caught 67 SOEs covering up losses of RMB 600 million ("Beijing moving to improve quality of statistics," South China Morning Post, February 29, 2000).
} 
experimentalist school tended to emphasize only the first and second factors, and to downplay the empirical validity of the second factor on the basis of the empirical work done by its members. The problem with the competition explanation is that the profit rates of SOEs in the sectors of industry that experienced little entry by non-SOEs showed the same dramatic drop as the profit rates of SOEs in sectors with heavy penetration by non-SOEs, see Fan and Woo (1996). Profits in SOEs fell regardless of whether they faced competition from non-SOEs.

The convergence view has emphasized continued inefficiency, and de facto assetstripping and embezzlement of firm profits by managers and workers as the primary causes for the general decline in SOE profits, with the latter being the more important. The devolution of financial decision-making power to the SOEs, and the steady reduction in discrimination against the private sector have made it increasingly easy for the managers to transfer state assets to themselves. In December 1995, the State Bureau for the Administration of State Property reported that asset-stripping in the SOE sector "has been about 50 billion yuan [annually] since the early 1980s." ${ }^{27}$ This would mean that the cumulative loss of SOE assets in the 1983-1992 period was equivalent to some 34 percent of the net value of fixed assets in the SOE sector as of 1992. It is hence, perhaps, only natural that of the 327 cases of embezzlement, bribery and misuse of public funds that were tried in Beijing in 1999, "76 percent took place in SOEs." 28 The increasing public outrage over the inequity of the informal privatisation of the SOE sector is well captured in the book by He Qinglian who wrote that the SOE reform has amounted to:

a process in which power-holders and their hangers-on plundered public wealth. The primary target of their plunder was state property that had been accumulated

\footnotetext{
27 "State asset drain must end," China Daily, December 13, 1995.

28 "Judicial Attention to SOEs Pledged," China Daily, February 19, 2000.
} 
from forty years of the people's sweat, and their primary means of plunder was political power. $^{29}$

The Chinese leadership recognizes clearly the increasingly serious economic and political problems created by the agency problem innate in the decentralizing reforms of market socialism. This is why the debate between the conservative reformers and the liberal reformers has progressed from whether privatization is necessary to the question of the optimal form and amount of privatization. Even then the state's decision in 1997 to accelerate diversification of the ownership structure of the SOEs has to be recognised to be a bold move because the experiences with mass privatization in Eastern Europe and the former Soviet Union (EEFSU) show that the task is an extremely difficult one and that the outcomes have consistently fallen below initial expectations. For example, in Russia, the "loans-for-shares" privatization transferred the country's enormous mineral wealth to a group of oligarchs, and the weak administrative and legal structures allowed many managers to take effective control of the privatized firms and loot them instead of improving their operations. Furthermore, the EEFSU experiences warn that mass privatization is an exceedingly dangerous business politically, no matter how it is done, be it outsider privatization or insider privatization. This is because the mass privatization of SOEs generates so much rent that massive corruption has not been avoided, and the resulting corruption inevitably delegitimises the government, e.g. Vaclav Klaus in the Czech Republic and Boris Yeltsin in Russia.

Despite the mediocre to poor privatisation outcomes in EEFSU, we still deem privatisation to be inevitable and desirable for China for two main reasons. The first reason comes from John Nellis (1999) who points out that "governments that botch privatization are

\footnotetext{
${ }^{29}$ He Qinglian, Zhongguo de Xianjing, (China's Pitfall), Mingjing Chubanshe, Hong Kong. The translated quote is from Liu Binyan and Perry Link, "China: The Great Backward?" The New York Review of Books, October 8, 1998, pp. 19.
} 
equally likely to botch the management of state-owned firms". The answer is not to avoid privatizations but to implement more careful privatizations: governments in transition economies should "push ahead, more slowly, with case-by-case and tender privatizations, in cooperation with the international assistance community, in hopes of producing some success stories that will lead by example."

The second reason lies in that the delay of privatization can be costly to China's government politically. Stealing by managers does occur during privatization and creates a social backlash against the government, but the maintenance of the status quo has become increasingly difficult because SOE managers in China know from the EEFSU experience that they are in an endgame situation. The widespread spontaneous privatization by SOE managers could create grave social instability.

To be accurate, we believe that the solution to the SOE problem in China is not privatisation per se, but a transparent, legal privatisation process that society at large can accept, at the minimum, as tolerably equitable. Because an adequate privatisation program must compensate the retired and layoff workers, permit takeover by core investors, and respect the rights of minority shareholders, it is important that legal reforms be carried out simultaneously. Only with a transparent, equitable privatisation process that is overseen by an adequate legal framework, would China be likely to avoid a state-created Russian-style kleptoklatura that would fuel social dissatisfaction.

Recently, there has been some questioning on whether the case for privatisation has been overstated. ${ }^{30}$ When Zhu Rongji was designated the new premier in 1997, he announced that he would solve the SOE problem in three years. In 2000, he declared victory on the SOE front when the profits of the industrial SOEs leaped from 53 billion yuan in 1998 to 241 billion in

\footnotetext{
${ }^{30}$ See Nolan and Wang (1999) for a recent assertion of a turnaround in SOE performance,.
} 
2000. This is indeed favorable news, but should be put in context. This improvement in SOE profitability was actually part of a general phenomenon, the profits of the industrial non-SOEs increased from 93 billion in 1998 to 199 billion in 2000 for a variety of macroeconomic reasons. ${ }^{31}$ While the rise in profits surely gives some breathing space, the capacity of SOEs to "dissipate rents" through high payments to managers and workers, if not illegal transfer of assets, should remain clearly in the policy makers' minds. Thus, any gains could well be squandered, if not reversed, in a relatively short period of time.

Table 3 summarises a study by Zhou and Wang (2002) who quantified the sources of the financial turnaround. They found that:

- the lower interest rate in 2000 increased profits by 52 billion yuan (28 percent of the increase in SOE profits);

- the higher oil prices boosted overall SOE profits by 79 billion yuan because almost all oil companies are state-owned (42 percent of the increase); ${ }^{32}$ and

- the conversion of the bank loans of SOEs into equities held by state asset management companies raised profits by 10 billion yuan ( 5 percent of the increase).

About 75 percent of the increase in the profits of industrial SOEs in the 1998-2000 period was not due to actions taken within these enterprises but to external factors. When Zhou and Wang (2002) calculated the profit rate after deducting the profits from the more favorable external environment, they found that it had increased from 0.7 percent in 1998 to 1.2 percent in 2000 for the SOE sector, and from 2.8 percent to 4.8 percent for the non-SOE sector. Despite the recent good news on SOE profitability, the fact remains that the SOE sector still lags considerably behind the non-SOE sector in efficiency.

\footnotetext{
${ }^{31}$ The non-SOE data exclude small non-SOEs with sales at or below 5 million yuan. Data in this paragraph are from Zhou and Wang (2002).

${ }^{32}$ This estimate has taken into account the additional production cost of the non-oil SOEs.
} 
Zhou and Wang (2002) bolstered their conclusion with Figure 4, which plots the profit rate in each of the 37 industrial sectors against the proportion of sectoral output produced by SOEs in 2000. It shows that the profit rate of the sector declined as the SOE presence in the sector increased.

\section{$\underline{\text { Section 4: WTO-induced Macroeconomic Shocks }}$}

\section{1: Import-Induced Unemployment}

Table 4 summarises the main institutional changes that WTO membership would require, e.g. tariffs on automobiles will fall from 90 percent to 25 percent, and state trading will be confined to cereals, tobacco, fuels and minerals. It is clear that the substantial liberalisation of trade in many services, and the lowering of the average industrial tariff from 24.6 percent to 9.4 percent by 2004 and the average agricultural tariff from 31.5 percent to 14.5 percent by 2004 will create considerable adjustment costs for China. For example, China is a natural food-importer and a natural factory-oriented society given its low land-man ratio, but its agricultural sector still employs over 332 million people, which is over two-third of the rural labor force. The bulk of China's state-owned sector relies on WTO-contravening policy instruments like subsidies and import barriers ${ }^{33}$ for survival, and this sector employs over forty percent of the urban labor force. Together, the agricultural sector and the state sector together employ about 60 percent of the total labor force. Conservatively, almost a fifth of China's workers might have to change jobs, and this could be a politically destabilizing process if not handled adeptly, and if external shocks were to slow down economic growth.

\footnotetext{
${ }^{33}$ This is why China has over 30 car-making firms when Japan, possibly the most efficient car manufacturer in the world, has only 5 .
} 
Gordon Chang's claim that WTO membership would involve considerable costs to China is undeniable. What is deniable is his second claim that WTO membership would definitely lead to the collapse of China's economy. In our view, it would require China's government to mishandle the macroeconomic difficulties in order to produce the collapse that Chang has envisaged. The fact is that the recent record of macroeconomic management in China has been between satisfactory to good. China has been facing deflation since 1997. Figure 5 shows negative growth of the producer price index from 1997:2Q to 2000:4Q, and then again since 2001:2Q. ${ }^{34}$ The expansionary fiscal and monetary policies that the authorities have undertaken have succeeded in keeping annual GDP growth at 7 to 8 percent.

The government's vigorous efforts at economic stimulation are summarized in Figures 6 and 7, and Table 5. The interest rate has been cut eight times in less than six years, with the latest rate cut on 21 February 2001, which brought the 1-year deposit rate to 1.98 percent and the 1-year lending rate to 5.31 percent. The annualized (year-on-year, yoy) growth rate of fixed asset investment of the state sector was kept above 15 percent from July 1998 to July 1999 period, and then lowered as exports to the other East Asian economics recovered. Fiscal stimulus was renewed in 2001. States spending on capital construction jumped from Rmb209.5 billion in 2000 to Rmb251.8 billion in 2001, which kept the annualized growth rate of state sector fixed asset investment above 15 percent for 11 of the 12 months in $2001 .^{35}$ When the CPI slipped again into negative growth rates falling in November 2001 (reaching -1.3 percent in

\footnotetext{
${ }^{34} \mathrm{~A}$ less severe picture of the deflationary pressures is given by the consumer price index, CPI, because it includes the prices of services.

${ }^{35}$ Apart from investment in capital construction, the government also implemented three pay rises since 1999. In 2001, for example, the public servants, including those employees of the state-run education and research institutions and military personnel, received a 30 percent increase in their base salaries plus the year-end bonus equivalent to one-month's base salary. Between 1998 and 2001, the Ministry of Finance issued a total of Rmb510 billion of treasury bonds for spending on infrastructure projects, especially in the western provinces. The government issued Rmb100 billion in 1998, Rmb110 billion in 1999, and Rmb150 billion each in 2000 and 2001. The planned issuance for 2002 is also Rmb150 billion.
} 
April 2002), the Chinese government increased the intensity of the fiscal stimulus e.g. the growth rate of state sector fixed asset investment has stayed above 25 percent since February $2002 .^{36}$ Most government economists tend to believe that the investment using funds raised through treasury bond issuance contributed about 2 percentage points to GDP growth each year during the past four years; Jia (2002).

Citigroup (2002) has estimated that the fiscal deficit will rise from 2.7 percent of GDP in 2001 to 3.1 percent in 2002. This expected fiscal deficit in 2002 will mark a further increase in what were already unprecedentedly high deficits in 2000 and 2001, see Table 5. So the important question about import-induced unemployment is whether there are technical and political obstacles that can prevent China from implementing macroeconomic policies (especially, fiscal policy) that are even more expansionary, and for a longer period.

We will, however, first turn to look at the possibility of WTO-induced bank collapse before answering this question. This is because, as we will see, the prevention of WTO-induced bank collapse is ultimately in part a fiscal issue as well.

\section{2: WTO Membership and the Problems in the Banking System}

China's banks are in undeniably serious financial straits. According to the People's Bank of China (PBOC), the proportion of non-performing loans (NPLs) of the four big state-owned commercial banks (SOCBs) is presently about 26 percent, which is 2 percentage points lower than a year ago. However, the recently revealed scandals of the Bank of China suggest that there are probably still undiscovered black holes in the banks' books. Table 6 presents estimates that

\footnotetext{
${ }^{36}$ The government has also announced a fourth round of pay increase to civil servants that would begin from July 1, 2002 (an increase that some economists have argued as excessive) "Fourth raise for China civil servants attacked," The Straits Times (Singapore), June 11, 2002.
} 
put NPLs to be 35 percent of outstanding loans at the four big SOCBs at the beginning of 2002, and the average capital adequacy ratio (CAR) of these four banks to be 5.0 percent.

The bank reform efforts of the past several years have failed. The proportion of NPLs has come down from its record high of 48 percent in 1998, but this reduction was achieved mainly by the transfer of the NPLs to the state-owned asset management corporations. The major portion of the transferred NPLs still needs to be disposed and is thus still the responsibility of the banks or the Ministry of Finance. Worse, most of the problem SOEs remain clients of the parent banks and continue to create new NPLs. What has facilitated the creation of new NPLs is the intermittent pressure on the banks from the government to expand investment credit to combat deflation, and to expand social stability loans to reduce firm closures. This is why the quality of banking assets has deteriorated rapidly during the past years, causing the capital adequacy ratio to fall to 5 percent in early 2002 from the 8-plus percent achieved in late 1998 after the recapitalization of the banks. The state banks are now in need of another round of recapitalization.

In this situation of a fragile banking system, China has committed itself to opening up the banking system completely within five years of joining WTO (which it joined in December 2001). Foreign banks could conduct transactions in foreign currencies from the beginning of WTO membership, conduct transactions with the local corporate sector in Renminbi after two years, and conduct transactions with local households in local currencies after five years. Although foreign banks are likely to compete only in the coastal cities, at least in the initial period, the pressure on domestic banks can be high as the big four banks extract about 95 perccent of their profits from about half a dozen coastal cities (Shanghai, Beijing, Xiamen, Shenzhen, Guangzhou, and Tianjin). Because there is no depositor insurance in China, the 
obvious question is whether depositors will believe that these foreign banks will drive the SOCBs into open bankruptcy, and hence rush to withdraw their savings from the SOCBs, setting in motion the vicious downward spiral of credit contraction, leading to business failures, rendering sound financial institutions insolvent, and contracting credit further.

Our reading is that even if pressures on the state banks do occur through depositor withdrawals, there is no need for a full-blown crisis, since the central bank will be able to issue currency to the state banks to meet the withdrawals. This expansion of high power money cannot be easily translated into a loss of foreign reserves because capital controls, which we support, remain in place and are likely to do so for the forseeable future. The resulting expansion of high power money will also not have much impact on inflation because this is mainly a shift out of bank deposits into cash, or from some banks to others, and not a shift into goods. (In fact, in the current deflationary situation, a shift into goods would be stabilising.) Simply put, the government has the technical ability to accommodate shifts in bank deposit preferences, even a modest bank run, without risking exchange rate collapse or a runaway inflation

However, the fact that the government can prevent a bank run from causing a financial meltdown is not good enough. If the banking system is plagued by frequent bank runs, its role as a financial intermediary will be greatly reduced, and economic growth could suffer significantly. The real issue is not whether depositor shifts, or a bank run, could be accommodated but how to prevent a banking crisis from occurring in the first place. Because depositors have the incentive to withdraw their funds as long as the banks are seen to be insolvent, the prevention of bank crises requires that the government keep the banks adequately capitalised at all times. Since the government had recapitalised the banks in 1998, and needs to do so again now, the important 
question is whether there are technical and political obstacles that can prevent China from implementing another round of bank recapitalization. Or, to put it differently, how many more rounds of bank recapitalization can China afford without generating a fiscal crisis?

\section{3: Difficulties in Fiscal Management}

For China, the prolonged use of loose fiscal policy carries two major risks. The first risk is low economic efficiency of the state investments, especially of many of the infrastructure projects implemented in the last four years. Almost all of these projects were implemented by the SOEs in a rush, with some of the projects were approved even before the feasibility reports were completed. In 1998 and 1999 there were frequent reports about the collapse of bridges and roads that were built recently. This risk of a rise in fiscal inefficiency has been confirmed by an internal study of the Ministry of Finance which found that the amount of investment required to create one additional unit of GDP has increased significantly in recent years; Gao (2002).

The second, and, possibly, more serious, risk to fiscal management is fiscal sustainability. The proactive fiscal policy contributes to fiscal risks in two ways — it directly increases both fiscal deficits and public debts, and indirectly increases the amount of NPLs by influencing banking lending decisions. A higher debt-GDP ratio means more debt servicing in future periods, and this could require expenditure cuts in order to prevent an upward spiral of the debtGDP ratio, a development that convince the financial markets that the state is resorting to Ponzi scheme to finance its deficits, and cause a shutoff of credit to the state.

The stock of publicly-acknowledged government debt comes to only 16 percent of GDP, and so it is usual to hear official assurances that the current fiscal deficits of less than 3 percent of GDP do not pose a problem for debt servicing by the state. However, if all the contingent 
liabilities are counted on a rather pessimistic assessment (which includes one more round of bank recapitalization, i.e. the second bank recapitalization since 1997), the consolidated public debt could be as high as 115 percent of GDP, see Table 7. Is China's debt-GDP ratio now too low or too high?

In order to make consistent international comparisons, we will drop the contingent claim of the social security system to arrive at 88.8 percent for China's debt-GDP ratio (after the yet-tooccur second round of bank capitalisation). The central government debt-GDP ratios in Italy, Sweden and the United States were, respectively, 117.6 percent, 70.8 percent, and 50.5 percent in $1995 .{ }^{37}$ The obvious conclusion from the international comparison is that a third bank recapitalization (after 1997) will put China in a riskier fiscal position that may even threaten its credit standing in the international financial markets. The forthcoming recapitalization of China's banks appears to be the last major one that the government could implement in the shortterm without risking the stability of the financial markets and the macroeconomic situation.

Assuming that the banking system does mend its ways after the second recapitalization, it might therefore appear that there is still substantial room for the Chinese government to increase its borrowing to finance its expansionary fiscal policy to counter any import-induced unemployment. However, such a conclusion would be overly optimistic. This is because China raises much less state revenue (as a share of GDP) than these other countries, and hence has a much lower capacity to service its public debt. The revenue-GDP ratio was 16.2 percent for China in 2001, 30 percent for Italy in 1995, 38 percent for Sweden in 1995, and 21 percent for the U.S. in $1996{ }^{38}$ The point is that until China increases its tax collection, there is a not much

\footnotetext{
${ }^{37}$ The US ratio is for 1996. Ratios were constructed from the IMF's International Financial Statistics.

${ }^{38}$ The revenue-GDP ratio for China is from Deutsche Bank (2002) which estimated that it will rise to 16.4 percent in 2002 and 16.6 percent in 2003. Debt-GDP and revenue-GDP ratios for other countries are from the IMF database.
} 
room to increase infrastructure investment to stimulate the economy. And it is important to note that increasing tax collection is as much a political challenge as it is an administrative challenge.

In summary, although China's present fiscal position is far from a crisis situation, it is not in good shape either. China's consolidated debt-GDP ratio is at the high end by international standard but its revenue-GDP ratio is on the low side. The greatest threat to China's fiscal sustainability, and hence economic stability, is the threat of successive rounds of bank recapitalization. This destabilising tendency is a systemic feature of the current banking system, and cannot be attributed to WTO membership. In fact, we shall argue below that WTO membership is likely to rehabilitate China's financial system, and, may, as a byproduct, reduce the deflationary tendencies evident since 1997.

\section{4: The Benefits of WTO to Macroeconomic Management}

At a superficial level, the systemic deflationary pressures that have plagued China since 1997 have their sources in two Keynesian maladies, the liquidity trap and the paradox of thrift. The liquidity trap refers to the phenomenon of the last few years where monetary policy does not seem to work. China has tried to boost the domestic economy with successive cuts in interest rates, but the rise in credit creation has been disappointing. Credit growth has much lower than expected, except for brief intervals when the central bank leaned heavily upon the banks. The paradox of thrift refers to the low level of private aggregate demand because the private saving rate has been increasing. The Chinese government has concluded that, because private aggregate demand is falling and monetary policy seems incapable of stimulating it, the key to maintaining macroeconomic stability is government spending. 
At a deeper level, however, both of these phenomena, we suggest, spring from the same cause, which is the absence of adequate financial intermediation in China. Why for example is China suffering from an apparent liquidity trap? The main reason seems to be that state bank managers have been told that if the ratio of non-performing loans were to go up two years consecutively, they would lose their jobs. The traditional client-base of the state banks is state enterprises, of which, half to two-third, are reporting zero or negative profits. By extending more loans to state enterprises, the non-performing loan ratio would inevitably rise. At the same time, state banks are also unwilling to lend to non-state enterprises and for very good reasons. First, the accounting practices of the non-state enterprises are neither uniform nor transparent. Second, it is politically more risky to do so. A loan to a state-owned enterprise might be a bad economic decision, but a loan to non-state enterprise that goes bad could potentially be a bad political decision as well. The bank manager could be accused of consorting with the private sector to embezzle the state. ${ }^{39}$ The liquidity trap arises then because the banks are not willing to lend money to either the state-owned enterprises or the private enterprises. The only activity that the banks are happy to allocate their funds to is the purchase of state bonds, i.e. the financing of the government's deficit. The fundamental step to eliminating the liquidity trap is to end the bias against lending to the private sector.

For the paradox of thrift, the right solution to the insufficient domestic demand in the Chinese economy is not mainly for the government to use up the private savings in public investments, but to set up mechanisms to channel private savings into increased private investments. This is where the entry of foreign banks will be exceedingly important. Foreign

\footnotetext{
${ }^{39}$ The Chinese government has sought to increase bank lending to private individuals by encouraging banks to establish mortgage loans, which are perceived as less risky because of their seemingly fully collateralized nature. Mortgage lending, however, is a totally new product to be provided to a totally new set of customers, and so the state banks have understandably been slow in setting up this market.
} 
banks will be concentrating their activities in the large coastal cities, where the state-owned banks are now making the bulk of their profits. This increased competition in the profit centers of the state-owned banks could push the state-owned banks to focus on areas of banking where they do have a comparative advantage over the foreign banks.

China's state-owned banks do have a comparative advantage in operating in the inner provinces and the rural areas because of their existing extensive branch systems. The state banks have traditionally neglected the inland provinces and the rural areas. The number of rural banks has actually decreased in the 1985-1995 period. One reason is that the regulated interest rate for loans in China made it unprofitable to extend small loans. Large loans and small loans require the same amount of paper work and time to process. It is only natural that rural banks should charge a higher interest rate since the cost of monitoring and processing the loan is higher. But because the government-set margin that rural branches can charge above the (also governmentset) lending rate in urban areas is too low to cover the additional costs and higher default risk, banks have retreated from lending in the rural areas. The liberalization of interest rates combined with increased competition in the coastal urban markets will motivate the state banks to expand their activities in the long-neglected inland provinces and rural areas.

What has been happening in the face of strong rural industrial growth is that a lot of informal rural financial institutions have sprouted to meet the financing needs of the rural industries. Given the illegal nature of these rural financial institutions, they live under the constant threat of closure, and so they tend to focus only on the short run and take more risks. It is not surprising that these risky rural financial institutions often failed. Whenever they failed, the government had to bail them out in order to maintain political stability. The government has therefore been clamping down even harder on these illegal financial intermediaries, because the 
government does not want to choose between the risk of bailing them out and the risk of having social instability. The government's increasing strict enforcement of the ban on private financial intermediation is the exact opposite to what ought to be done. The efficient solution is to allow private financial intermediaries in the rural area, and bring them under proper prudential supervision.

The general principle, and a trend that the Chinese government will find increasingly costly to prevent, is to reduce interest rate controls and allow private banks to come into existence. The improvement in financial intermediation induced by WTO membership can help to eliminate the liquidity trap and reduce the paradox of thrift through improved financial intermediation, and hence ease the task of macroeconomic management. ${ }^{40}$

The entry of foreign banks will also improve financial intermediation by enabling the transfer of modern banking technology through a seldom-mentioned channel. In the future, when a successful Chinese enterprise group establishes a bank, it will do by hiring away the local managers employed by the foreign owned banks. This is exactly the Southeast Asian experience -- almost all the top managers of all the biggest domestic banks were ex-employees of foreign banks. This is perhaps what the Chinese leadership sees and why it is willing to allow the entry of foreign banks, giving them national treatment within five years of WTO membership. The Chinese leadership is betting that in the short-run, there could be significant displacement of Chinese state banks by foreign banks, but in the long run, Chinese banks (most likely private ones) will rise in importance. Twenty years from now, the international financial world will have more to fear from Chinese banks than vice-versa.

\footnotetext{
${ }^{40}$ For a formal model and empirical investigation of the macroeconomic consequences of inadequate financial intermediation (in other countries, especially in Taiwan), see Liu and Woo (1994).
} 
We should mention that entry of Western banks into China's financial markets is not the same thing as capital market liberalization. We do not believe that China would be well served by a rapid opening of the capital account, since that could subject China to rapid swings of shortterm capital in the same manner that has whipsawed the economies of Southeast Asia and Latin America. Capital market liberalization should proceed gradually and in stages, because it must be accompanied by sophisticated financial market regulation, something that is clearly not in place at this time. We do not relish the phenomenon of foreign banks suddenly becoming a conduit for large-scale capital flight, or for rapid swings in short-term lending and repayments, or as facilitators of bank runs (in which depositors do not merely switch banks, or switch from domestic banks to domestic currency, but actually switch from domestic deposits to foreign assets).

Finally, we must now mention that there has been too little attention given to the fact that WTO membership also creates new employment, especially by ensuring the access of Chinese exporters to markets in the United States, Europe, and other regions. China's entry into the WTO will allow several big Chinese exports greater access to the markets in the United States and Western Europe, e.g. the multi-fiber agreement would be ended. Instead of China losing its shirt because of entry to WTO, Chinese textile industry would expand. Labor-intensive exports will expand more generally to offset some of the increase in imports. For the same reason, WTO membership could increase the flow of foreign direct investments into China in export-oriented sectors, and this will certainly create new (and, most likely, also higher paying) jobs. Figure 8 shows that the level of utilised foreign direct investment into China has been increasing every 
month December 2000, when there was no longer any doubt that China would soon become a WTO member. ${ }^{41}$

\section{$\underline{\text { Section 5: Final Remarks }}$}

China's entry into the World Trade Organization (WTO) marks a watershed on many fronts for China. First and foremost, China's admission into WTO marks an important improvement in the economic security of China. Trade and foreign investment have constituted an important engine of growth since 1978. The requirement for annual renewal by the U.S. Congress of China's normal trading relationship with the United States made China's economic growth vulnerable to the vagaries of American domestic politics. Through WTO membership, this engine of growth could no longer be unilaterally shut off by the United States without the action being a major violation of U.S. international commitments.

WTO membership also marks a watershed in China's public recognition about the primary source of its impressive growth in the last two decades. The WTO is an international economic organization that specifies and enforces broadly similar economic policy regimes on its membership. China's willingness to join such an institution reflects more than a desire to protect itself from potential economic blackmail by the United States. It also reflects China's realization that the active ingredient in Deng Xiaoping's recipe for conjuring up growth was the convergence of China's economic institutions with the economic institutions of modern capitalist economies, particularly of East Asian capitalist economies, as well as the closer integration of China's economy with the world economy through trade and finance.

\footnotetext{
${ }^{41}$ The jump in the amount of contracted FDI had occurred earlier when China completed its WTO bilateral negotiation with the United States.
} 
After twenty years of evolution in economic institutions, of rotation in political leadership, and of tectonic change in the political fortune of the communist parties in EEFSU, the only organized opposition today to the continued convergence of China's economic institutions to international forms comes from a small group of sentimental Stalinists like Deng Liqun. ${ }^{42}$ The social and political landscape in China has changed so much that the political leadership now incurs only minimal ideological liability when they introduce more capitalist incentives (e.g. differentiated pay, leveraged buy-out, stock options for managers) and capitalist tools (e.g. joint-stock company, bankruptcy law, unemployment insurance). The leadership is confident that its explicit embrace of capitalist institutions under WTO auspices would be seen by the general Chinese public (and the Chinese elite) as a step forward in the reform process rather than as surrender of China's sovereignty in economic experimentation.

China's accession to WTO also constitutes a watershed in the debate between the convergence school and the experimentalist school. To appreciate this point fully, the WTO membership must be viewed in the context of the comprehensive transformation of China's economy and society that began with the 12th Party Congress in 1992, and accelerated after the 17th Party Congress in 1997. Most of the small and medium SOEs in the rich coastal provinces have been privatised, and the government is now exploring ways to sell the state shares of the large SOEs that are listed on the domestic stock markets. The constitution has been amended to accord equal legal protection to state and private property; and the latest ideological breakthrough, The Three Represents, allows the admission of capitalists into the Party. The rural landscape has also changed greatly by the ongoing privatisation (since 1993) of the collectivelyowned TVEs. The extension of land leases from 15 years to 30 years will be recognised as a

\footnotetext{
42 "Elder warns on economic change," South China Morning Post, January 13, 2000, and "Leftists make late bid to slow reforms," South China Morning Post, February 10, 2000.
} 
landmark on the way to private land ownership in the countryside. WTO membership is, hence, only one of the many policy actions led by the state to promote the convergence of China's economy to the norms of its East Asian neighbors and integration with the world's major economies.

There are other WTO-induced developments that could potentially have large consequences on China's growth, and which we have not discussed in this paper. One major issue, and an excellent research topic, is how WTO membership may affect regional income and growth disparities, especially the disparities between Easter and Western China and between rural and urban China. The international experience is that coastal regions in a large country are, in general, richer than the inland regions because participation in international trade creates wealth, and coastal regions are more advantageously located to participate in global trade. So China's WTO membership could widen the already substantial income gap between its coastal and inland provinces. The concern is that even though the faster growth of the coastal provinces may not be occurring at the expense of the inland provinces, increased income disparity per se could lead to political problems. This is a threat to China's national unity that has been raised by many observers. ${ }^{43}$ Regional disparity is peculiarly a large-country problem, and so there is a much more limited pool of international experiences to draw upon to guide policy-making. In a situation like this, some degree of economic experimentation will be needed in order to arrive at the appropriate region-specific development strategies.

\footnotetext{
${ }^{43}$ For example, Wang Shaoguang and Hu Angang (1999) wrote: "Geographical imbalance is a politically divisive issue that can undermine national unity ... On the one hand, there is apt to be a widespread sense of frustration and deprivation in regions where incomes are strikingly low. Residents of those regions may readily believe that an insufficiently sympathetic central government is partly responsible for their plight. On the other hand, moredeveloped regions frequently perceive central redistributive intervention of any kind as unfair siphoning off of their resources ... [The result is that] rich regions may be attracted to the idea that their interests would be better served by an independent development path. Especially when such regions are more closely integrated with the world economy than with other regions in the same country, or when ethnic, religious, or linguistic differences coincide with economic differences, separatist temptations are more likely to emerge."
} 


\section{$\underline{\text { References }}$}

Aslund, Anders, Peter Boone and Simon Johnson, 1996, "How to Stabilize: Lessons from Postcommunist Countries," Brookings Papers on Economic Activity, Issue 1, pp. 217-313.

Berg, Andrew, Eduardo Borensztein, Ratna Sahay, and Jeromin Zettelmeyer, "The Evolution of Output in Transition Economies: Explaining the Differences," International Monetary Fund, WP/99/73, 1999.

Bouin, Olivier, 1998, "Financial Discipline and State Enterprise Reform in China in the 1990s," in Olivier Bouin, Fabrizio Coricelli and Francoise Lemoine (ed.), Different Paths to a Market Economy: China and European Economies in Transition, OECD, Paris.

Chang, Gordon, 2001, The Coming Collapse of China, Random House, NY, NY.

Chow, Gregory, 1993, "Capital Formation and Economic Growth in China," Quarterly Journal of Economics, August.

Citigroup, 2002, Greater China Insights, 14 June.

Deutsche Bank, 2002, Emerging Markets Monthly, 4 September.

Ellman, Michael and Vlaclimor Kontorovich, 1998, The Destruction of the Soviet Economic System: An Insiders' History, M. E. Sharpe, Armonk.

Fan, Gang and Wing Thye Woo, 1996, "State Enterprise Reform as a Source of Macroeconomic Instability," Asian Economic Journal, November.

Gao, Jian, 2002, 'China's financial system and financial market reform: WTO participation and its challenge to China's financial sector', presentation at the Citigroup Investors' Seminars, 8 May 2002, Shanghai.

Garnaut, Ross and Yiping Huang, 2001, Growth Without Miracles: Readings on the Chinese Economy in the Era of Reform, Oxford University Press, New York.

Groves, Theodore, Yongmiao Hong, John McMillan, and Barry Naughton, 1994, "Autonomy and Incentives in Chinese State Enterprises," Quarterly Journal of Economics, Vol. 109 No. 1, February, pp. 185-209.

Groves, Theodore, Yongmiao Hong, John McMillan, and Barry Naughton, 1995a, "Productivity Growth in Chinese State-Run Industry," in Fureng Dong, Cyril Lin and Barry Naughton, ed., Reform of China's State-Owned Enterprises, MacMillan, London.

Groves, Theodore, Yongmiao Hong, John McMillan and Barry Naughton, 1995b, "China's Evolving Managerial Labor Market," Journal of Political Economy, Vol. 103 No. 4, August, pp. 873-892. 
Huang, Yiping and Xin Meng, 1995, "China's Industrial Growth and Efficiency: A Comparison between the State and the TVE Sectors," Research School of Pacific Studies, Australian National University, manuscript.

Huang, Yiping Huang, Wing Thye Woo, and Ron Duncan, 1999, "Understanding the Decline of China's State Sector," MOCT-MOST: Economic Policy in Transitional Economies.

Jefferson, Gary, Thomas Rawski, and Yuxin Zheng, 1992, "Growth, Efficiency, and Convergence in China's State and Collective Industry," Economic Development and Cultural Change, Vol. 40 No. 2, January, pp.239-266.

Jefferson, Gary, Thomas Rawski, and Yuxin Zheng, 1996, "Chinese Industrial Productivity: Trends, Measurement Issues, and Recent Developments," Journal of Comparative Economics, Vol. 23, pp. 146-180.

Jia, Kang, 2002, 'Fiscal Policy in China after WTO Entry', presentation at the Citigroup Investors' Seminars, 8 May 2002, Shanghai.

Kornai, Janos, 1980, Economics of Shortage, North Holland, New York.

Lau, Lawrence J., Yingyi Qian and Gerard Roland, "Reform without Losers: An Interpretation of China's Dual-Track Approach to Transition," Journal of Political Economy, February 2000.

Lin, Justine Yifu, Fang Cai and Zhou Li, 1996, The China Miracle: Development Strategy and Economic Reform, Chinese University Press, Hong Kong.

Liu, Liang-Yn, and Wing Thye Woo, 1994, "Saving Behavior under Imperfect Financial Markets and the Current Account Consequences," Economic Journal, May.

McMillan, John, and Barry Naughton, 1992, "How to Reform a Planned Economy: Lessons from China," Oxford Review of Economic Policy, Vol. 8, No. 1, pp.130-143, Spring.

Naughton, Barry, 1994, "Chinese Institutional Innovation and Privatization from Below," American Economic Review, Vol. 84 Vol. 2, May, pp. 266-270.

Naughton, Barry, 1995a, Growing Out of the Plan:Chinese Economic Reform, 1978-1993, Cambridge University, Press.

Naughton, Barry, 1995b, "Economic Reform and Enterprise Transformation in China," paper presented at conference on Economic Reform and Enterprise Restructuring in China, September 21-22, 1995, Saint-Malo, France.

Nellis, John, 1999, “Time to Rethink Privatisation in Transition Economies?” International Finance Corporation Discussion Paper No. 38, World Bank. 
Nolan, Peter and Robert Ash, 1995, "China's Economy on the Eve of Reform," The China Quarterly, No. 144, December, pp.980-998.

Nolan, Peter and Wang Xiaoqiang, 1999, "Beyond Privatization: Institutional Innovation and Growth in China's Large State-Owned Enterprises," World Development, Vol. 27 No. 1, pp. 169200.

Ohkawa, Kazushi and Henry Rosovsky, 1973, Japanese Economic Growth: Trend Acceleration in the Twentieth Century, Stanford University Press, Stanford, California.

Parker, Elliott, 1995, "Shadow Factor Price Convergence and the Response of Chinese StateOwned Construction Enterprises to Reform, " Journal of Comparative Economics, Vol 21 No. 1, August, pp. 54-81.

Parker, Elliott, 1997, "The Effect of Scale on the Response to Reform by Chinese State-Owned Construction Units," Journal of Development Economics.

Perkins, Frances, Zheng Yuxing and Cao Yong, 1993, "The Impact of Economic Reform on Productivity Growth in Chinese Industry: A Case of Xiamen Special Economic Zone," Asian Economic Journal, Vol. 7, No. 2, pp. 107-146.

Reynolds, Bruce (ed.) Reform in China: Challenges and Choices, M.E. Sharpe, New York, 1987.

Reidel, James and Bruce Comer, 1996, "Transition to Market Economy in Vietnam," in Wing Thye Woo, Stephen Parker and Jeffrey Sachs (ed.), Economies in Transition: Comparing Asia and Europe, MIT Press, Cambridge, Ma.

Sachs, Jeffrey, and Wing Thye Woo, 1994, "Structural Factors in the Economic Reforms of China, Eastern Europe, and the Former Soviet Union," Economic Policy, April.

Sachs, Jeffrey, and Wing Thye Woo, 2000a, "Understanding China's Economic Performance," Journal of Policy Reform, Volume 4, Issue 1.

Sachs, Jeffrey and Wing Thye Woo, 2000b, "Understanding that Asian Finacial Crisis in Wing Thye Woo, Jeffrey D. Sachs, and Klaus Schwab, editors, The Asian Financial Crisis : Lessons for a Resilient Asia, MIT Press, Cambridge, Massachusetts.

Wang, Shaoguang, and Hu, Angang, 1999, The Political Economy of Uneven Development, The Case of China. Armonk, New York: M. E. Sharpe.

Weitzman, Martin and Chenggang Xu, 1994, "Chinese Township Village Enterprises as Vaguely Defined Cooperatives," Journal of Comparative Economics, Vol. 18, pp. 121-145.

Woo, Wing Thye, 1998, "“Chinese Economic Growth: Sources and Prospects," in Michel Fouquin and Francoise Lemoine (ed.), The Chinese Economy, Economica, London. 
Woo, Wing Thye, 2000, "Improving Access to Credit in Rural China," in Baizhu Chen, J. Kimball Dietrich and Yi Feng (ed.), Financial Market Reform in China: Progress,Problems and Prospects, Westview Press.

Woo, Wing Thye, 2001, "Recent Claims of China's Economic Exceptionalism: Reflections Inspired by WTO Accession," China Economic Review, Vol. 12, No. 2/3.

Woo, Wing Thye, Wen Hai, Yibiao Jin, and Gang Fan, 1994, "How Successful Has Chinese Enterprise Reforms Been? Pitfalls in Opposite Biases and Focus" Journal of Comparative Economics, June, pp. 410-437.

World Bank, 1996, The Chinese Economy: Fighting Inflation, Deepening Reforms, Washington D.C.

Wu, Harry Xiaoying and Yanrui Wu, 1994, "Rural Enterprise Growth and Efficiency," in Christopher Findlay, Andrew Watson and Harry Wu (ed.), Rural Enterprises in China, St. Martin's Press, New York, New York.

Zhou, Fangsheng and Xiaolu Wang, 2002, "The Way of State Owned Enterprise Reform in China," National Economic Research Institute, Beijing, China.

Zhou, Kate Xiao, 1996, How the Farmers Changed China: Power of the People, Westview Press, Boulder, Colorado.

Zweig, David, 1997, Freeing China's Farmers: Rural Restructuring in the Reform Era, M.E. Sharpe, Armonk, New York. 

Table 1: Production of Light and Heavy Industrial Goods, and State Sector Employment, 1978-1998

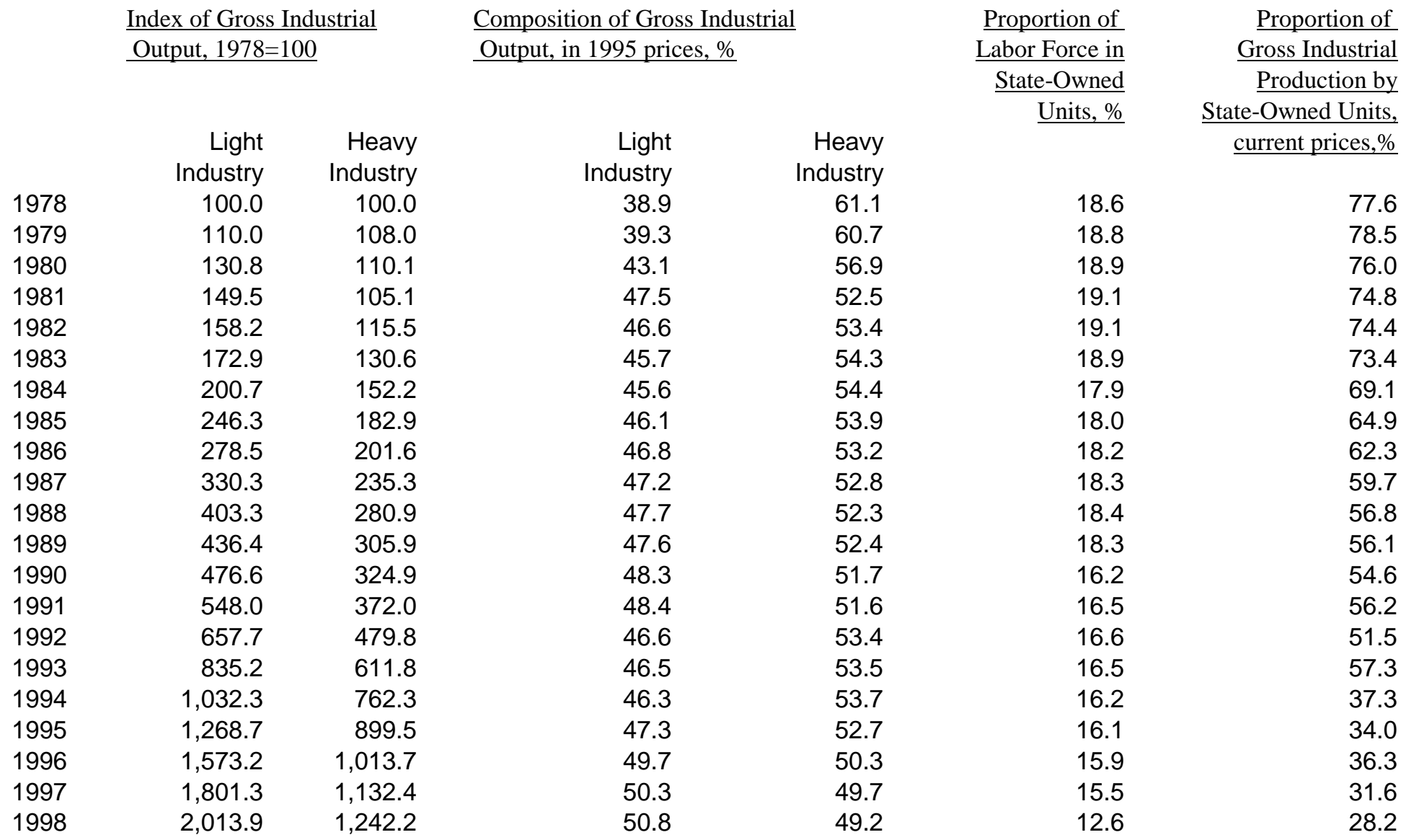

Data caluculated from State Statistics Bureau, Comprehensive Statistical Data and Materials on 50 Years of New China, 1999. 
Table 2: Growth Accounting

\begin{tabular}{|c|c|c|c|}
\hline (in percentage points per annum) & $\frac{1979-1993}{(\text { Woo, } 1998)}$ & $\frac{1985-1993}{(\text { Woo, } 1998)}$ & $\frac{1985-1994}{\text { (World Bank, 1996) }}$ \\
\hline official growth rate & 9.3 & 9.7 & 10.2 \\
\hline 1995 revision of $1985-93$ data & & & 0.3 \\
\hline inconsistent use of base years & 0.2 & 0.3 & $0.3^{1}$ \\
\hline overstatement of industrial output & 0.5 to 0.7 & 0.9 to 1.2 & $1.0^{2}$ \\
\hline capital accumulation & 4.9 & 5.5 & $6.6^{3}$ \\
\hline labor force growth & 1.3 & 1.1 & $\begin{array}{l}\text { (incorporated in } \\
\text { capital accumulation) }\end{array}$ \\
\hline $\begin{array}{l}\text { reallocation of labor from } \\
\text { agriculture }\end{array}$ & 1.1 & 1.3 & 1.1 \\
\hline net TFP growth & 1.1 to 1.3 & 0.3 to 0.6 & $0.9^{4}$ \\
\hline
\end{tabular}

Notes

1. Although the World Bank data are from a table identified as based on 1990 prices (Table 4, Vol. II, World Bank, 1996b), the GDP growth rates are identical to the official growth rates that are calculated from different base year prices - suggesting that the World Bank data have not been consistently re-based. We used Woo's estimate for 1985-93 to adjust the World Bank data.

2. Based on footnote 7 in pp. 32 of Volume II in World Bank (1996).

3. This figure is the sum of the contribution from capital stock growth and the contribution from labor force growth.

4. The reallocation of ownership accounted for 0.2 percentage point of this effect. 
Table 3. Analyzing sources of profit growth in SOEs and Non-SOEs (1998-2000)

Units: 100 million Yuan

\begin{tabular}{|c|c|c|c|c|c|c|c|}
\hline & \multicolumn{4}{|c|}{ SOE } & \multicolumn{3}{|c|}{ Non-SOE } \\
\hline & 1998 & 2000 & Change & $\operatorname{Exp}$ & 1998 & 2000 & Change Exp \\
\hline Total profit & 525 & 2408 & 1883 & $(100 \%)$ & 933 & 1985 & $1052(100 \%)$ \\
\hline \multicolumn{8}{|l|}{ From } \\
\hline Interest rate reduction & & & 523 & $(27.8 \%)$ & & & $300(28.5 \%)$ \\
\hline Higher oil price & & & 791 & $(42.0 \%)$ & & & $-341(-32.4 \%)$ \\
\hline Loan-equity swap & & & 101 & $(5.4 \%)$ & & & \\
\hline Residual = Own Effort & & & 468 & $(24.8 \%)$ & & & $1093(103.9 \%)$ \\
\hline Real return rate & $0.7 \%$ & $1.2 \%$ & $0.5 \%$ & & $2.8 \%$ & $4.8 \%$ & $2.0 \%$ \\
\hline
\end{tabular}

Note: Data in parentheses under "Exp" are share of contribution by different factors to total profit changes. "Real return rate" for 2000 is calculated as the ratio of total profit, excluding profits that resulted from the three external factors, to total assets. The estimate on the effect of higher oil prices has taken into account the additional production cost of the non-oil SOEs.

Source: Zhou and Wang (2002). Some terms used here differ from the source.

\section{Table 4. Summary of Key Commitments by the Chinese Government on WTO Membership}

\begin{tabular}{|c|c|}
\hline Sectors & Key Commitments \\
\hline Agriculture & $\begin{array}{l}\text { Farm subsidy capped at } 8.5 \% \text { of value of domestic production (current level }=2 \% \text { ) } \\
\text { Elimination of export subsidies } \\
\text { Average bound tariff down to } 15 \%(1-3 \% \text { in-quota rate and up to } 65 \% \text { above-quota } \\
\text { rate on cereals), further reductions mostly by } 2004\end{array}$ \\
\hline Automobiles & $\begin{array}{l}\text { Import tariffs on automobiles to } 25 \% \text { by mid- } 2006 \text { from current } 80-100 \% \\
\text { Restrictions on category, type and model of vehicles produced to be lifted in two years }\end{array}$ \\
\hline Banking & $\begin{array}{l}\text { Foreign bank involvement in foreign currency business permitted immediately, and } \\
\text { local currency business with local corporations within two years after accession, with } \\
\text { local residents within five years. Geographic restrictions on foreign banking business } \\
\text { to be lifted over five years }\end{array}$ \\
\hline Insurance & $\begin{array}{l}\text { Foreign ownership: } 50 \% \text { of life-insurance and } 100 \% \text { of nonlife insurance } \\
\text { (property/casualty) geographic/business restrictions will be gradually phased out }\end{array}$ \\
\hline Securities & $\begin{array}{l}\text { Minority foreign-owned joint ventures in fund management industry } \\
\text { Foreign ownership up to } 49 \% \text { in five years }\end{array}$ \\
\hline Distribution & $\begin{array}{l}\text { Foreign companies are allowed to set up joint ventures within two years after } \\
\text { accession with majority ownership and without geographic restrictions, with exceptions } \\
\text { for a few products }\end{array}$ \\
\hline Telecommunications & $\begin{array}{l}\text { Foreign company stakes: } 25 \% \text { in mobile phone, up to } 35 \% \text { in one year and } 49 \% \text { after } \\
\text { three years; area restriction will be lifted after } 5 \text { years }\end{array}$ \\
\hline $\begin{array}{l}\text { State trading and } \\
\text { trading rights }\end{array}$ & $\begin{array}{l}\text { State trading will continue in cereals, tobacco, fuels and minerals } \\
\text { All enterprises will be free to import or export after } 3 \text { years }\end{array}$ \\
\hline
\end{tabular}

Source: Compiled by the Citigroup from WTO documents 
Table 5. Growing Fiscal Spending

\begin{tabular}{|c|c|c|c|c|c|c|}
\hline & $\begin{array}{c}\text { Fiscal } \\
\text { revenue } \\
\text { (Rmb billion) }\end{array}$ & $\begin{array}{c}\text { Fiscal } \\
\text { expenditure } \\
\text { (Rmb billion) }\end{array}$ & $\begin{array}{c}\text { Fiscal } \\
\text { Balance } \\
\text { (Rmb billion) }\end{array}$ & $\begin{array}{c}\text { Share } \\
\text { of GDP } \\
(\%)\end{array}$ & $\begin{array}{c}\text { Spending } \\
\text { on capital } \\
\text { construction } \\
\text { (Rmb billion) }\end{array}$ & $\begin{array}{c}\text { Share } \\
\text { of GDP } \\
(\%)\end{array}$ \\
\hline 1997 & 865.1 & 923.4 & -58.2 & -0.7 & 102.0 & 1.4 \\
\hline 1998 & 987.6 & 1079.8 & -92.2 & -1.1 & 138.8 & 1.8 \\
\hline 1999 & 1144.4 & 1318.8 & -174.4 & -1.9 & 211.7 & 2.6 \\
\hline 2000 & 1339.5 & 1588.7 & -249.1 & -2.5 & 209.5 & 2.4 \\
\hline 2001 & 1637.1 & 1884.4 & -247.3 & -2.7 & 251.8 & 2.6 \\
\hline
\end{tabular}

Source: Citigroup (2002).

Table 6. Rising Fragility of China's Banking Sector

\begin{tabular}{lccc}
\hline & End-1996 & End-1998 & Beginning-2002 \\
\hline Proportions of NPLs (\%) & & & \\
Big four banks & 40.0 & 48.0 & 35.0 \\
$\quad$ Ten joint-stock banks & - & 13.5 & 15.5 \\
Average CAR (\%) & & & \\
$\quad$ Big four banks & 4.4 & $>8.0$ & 5.0 \\
\hline
\end{tabular}

Notes: NPLs: nonperforming loans; CAR: capital adequacy ratio. Proportion of non-performing loans for the four major banks for 1996 and 1998 are re-estimated based on new information made available at the beginning of 2001. The proportion for 2001 excluded the Rmb1.4 trillion transferred to the Asset Management Companies in the previous year.

Source: Citigroup estimates.

Table 7. Contingent Liabilities in China, End of 2001

\begin{tabular}{lcc}
\hline & RMB billion & \% of GDP \\
\hline Accumulated public debts & 1,550 & 16.2 \\
Special T-bonds in 1998 for recapitalization & 270 & 2.8 \\
Estimated costs for bank restructuring & 4,500 & 46.9 \\
Estimated costs for social security funds & 2,500 & 26.1 \\
Municipal government contingent debt & 700 & 7.3 \\
External debts & 1,500 & 15.6 \\
Total & 11,020 & 114.9 \\
\hline
\end{tabular}

Note: This is an updated estimation based on new information available on both gaps in social security funds and municipal government contingent debts that the central government is the guarantor for. These were estimated based on communication with government economists.

Source: Citigroup estimates. 
Figure 1: Consequences of big-bang reform in an initially inefficient economy with an irrationally large heavy industrial sector according to Lin, Cai and $\mathrm{Li}$ (1999). The composition of output moves from B to E via F. Each downward sloping line represents an income level, with income level increasing in the northeast direction.

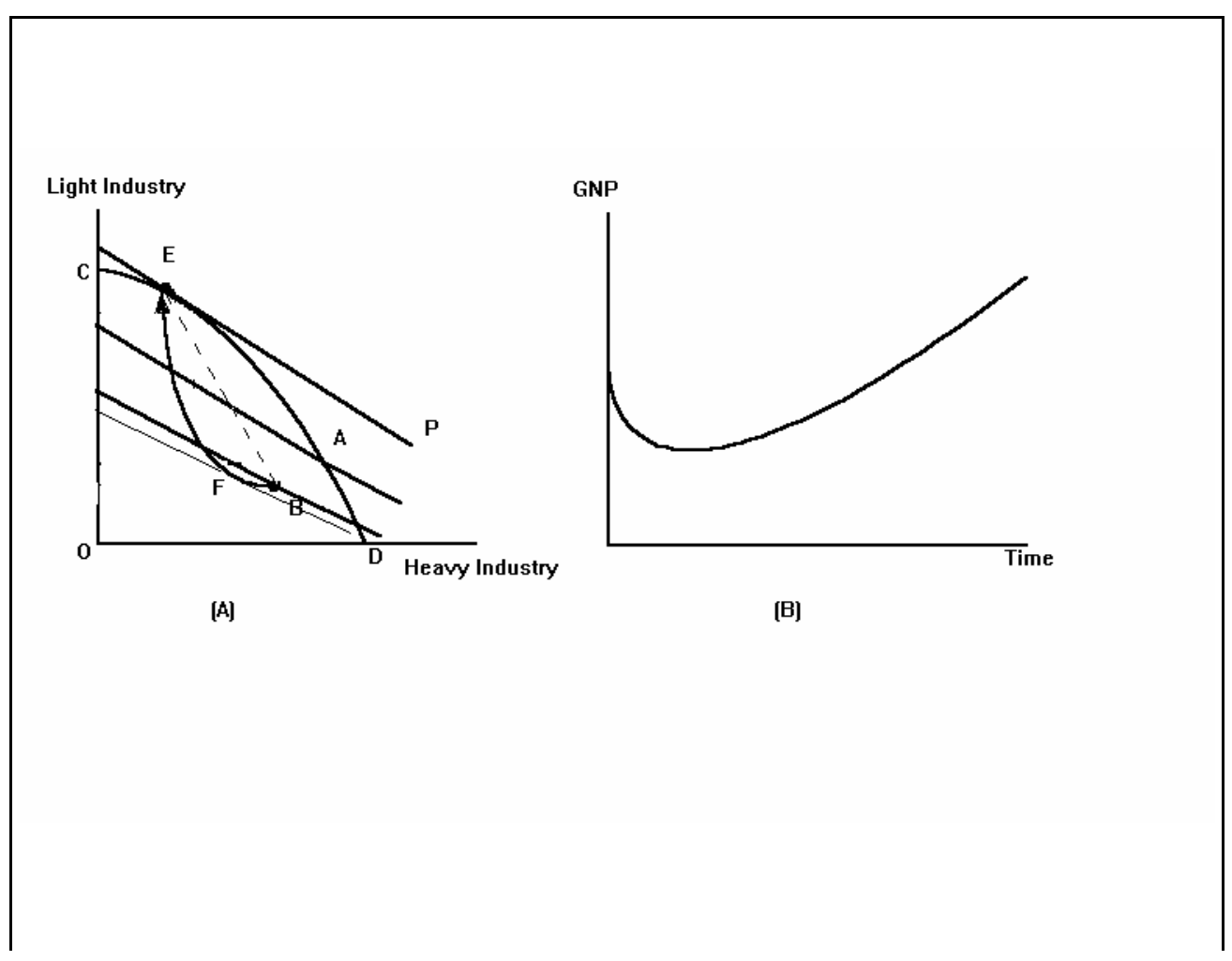


Figure 2: Consequences of gradual reform in an initially efficient economy with an irrationally large heavy industrial sector according to Lin, Cai and Zhou (1999). The composition of output moves from B to G via A. Each downward sloping line represents an income level, with income level increasing in the northeast direction.

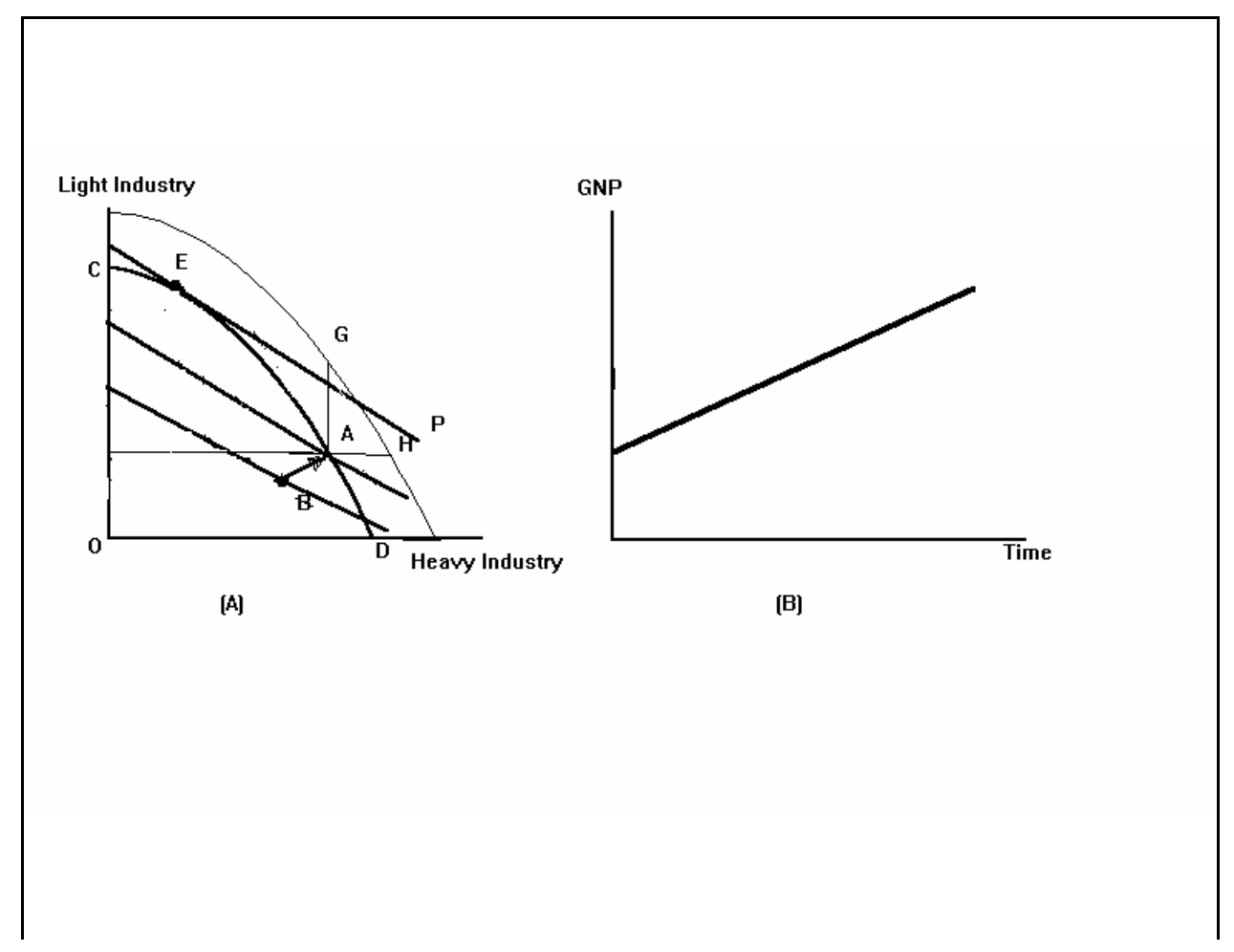


Figure 3

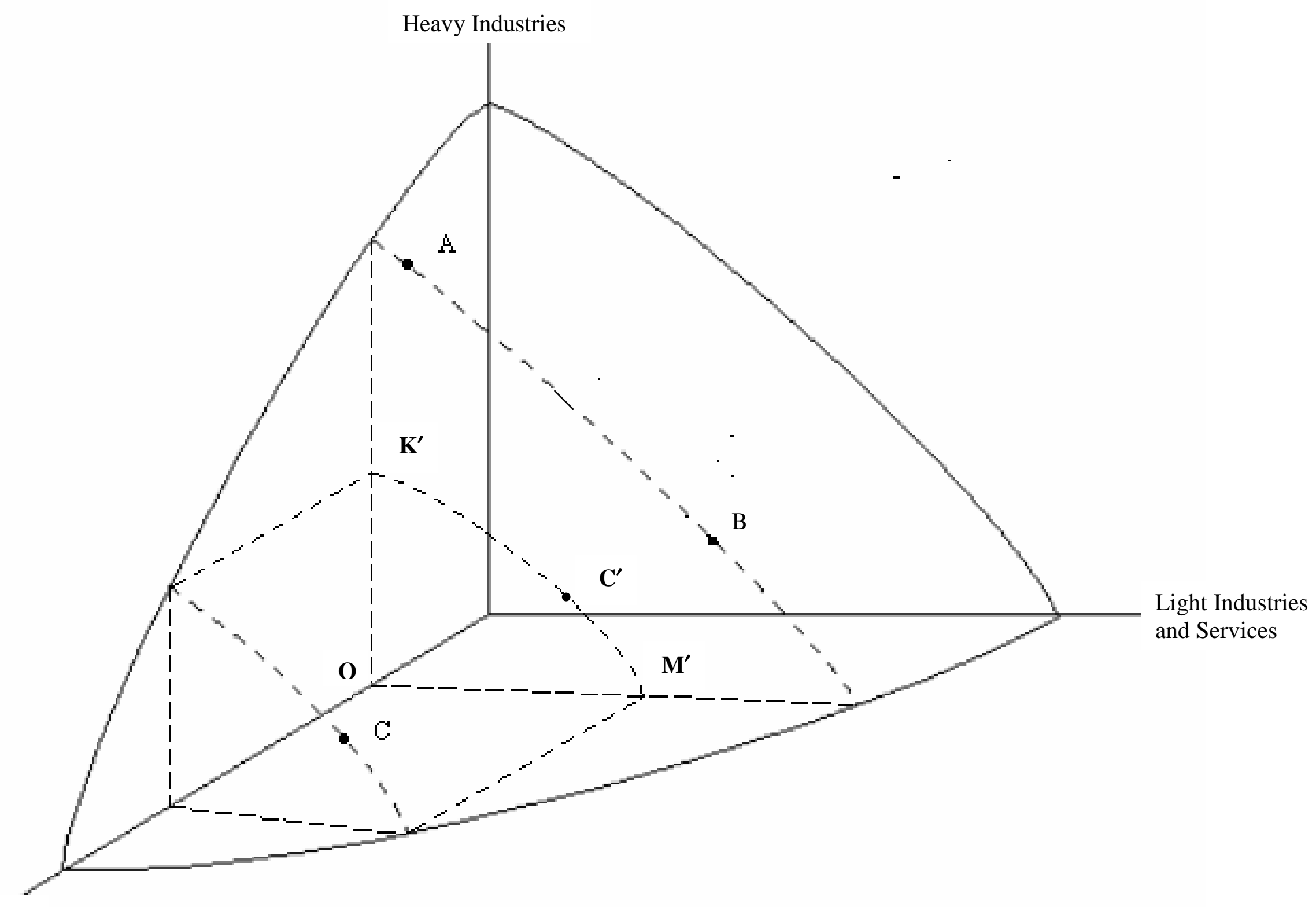

Agriculture 
Figure 4. The relationship between profitability and state dominance in different industrial sectors in 2000

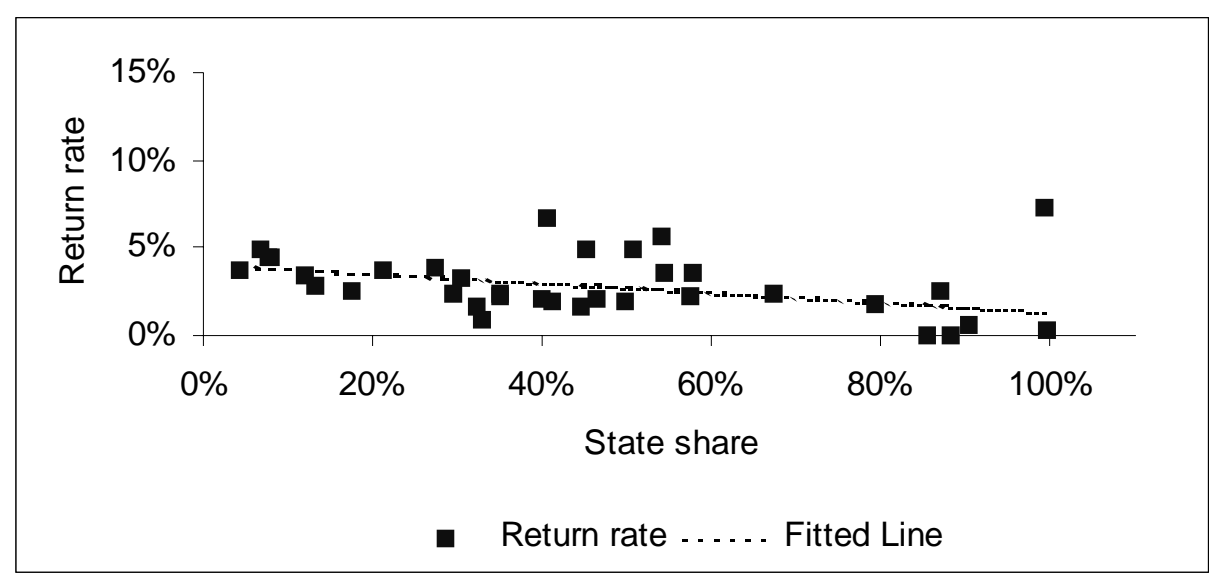

Note: Data are for 37 industrial branches. The return rate is defined as the ratio of total profit to total assets of each industrial branches. Source: Zhou and Wang (2002). 



\section{Figure 5. Price Deflation in China}

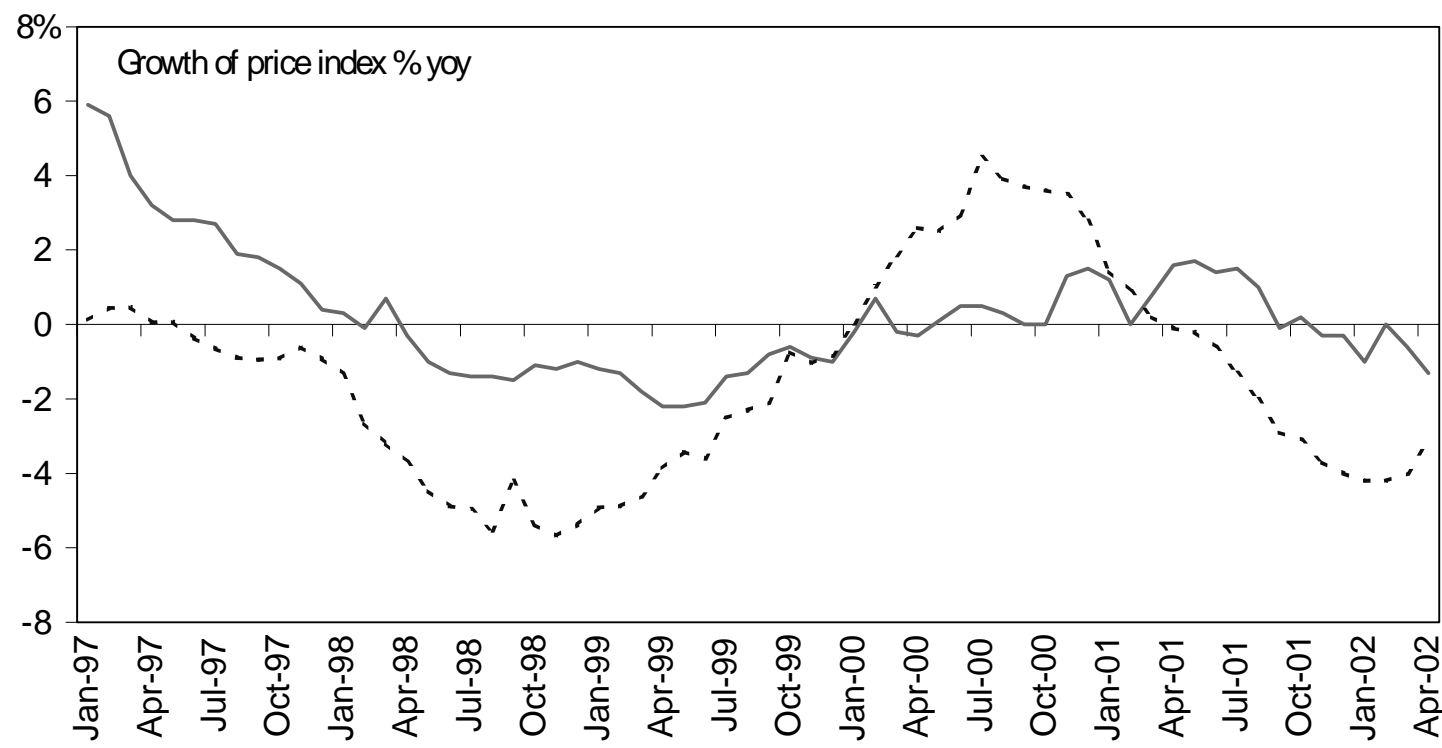

—Consumer Price Index - - - Producer Price Index

Source: Citigroup (2002).

\section{Figure 6. Growth of Money Supply and Interest Rates}

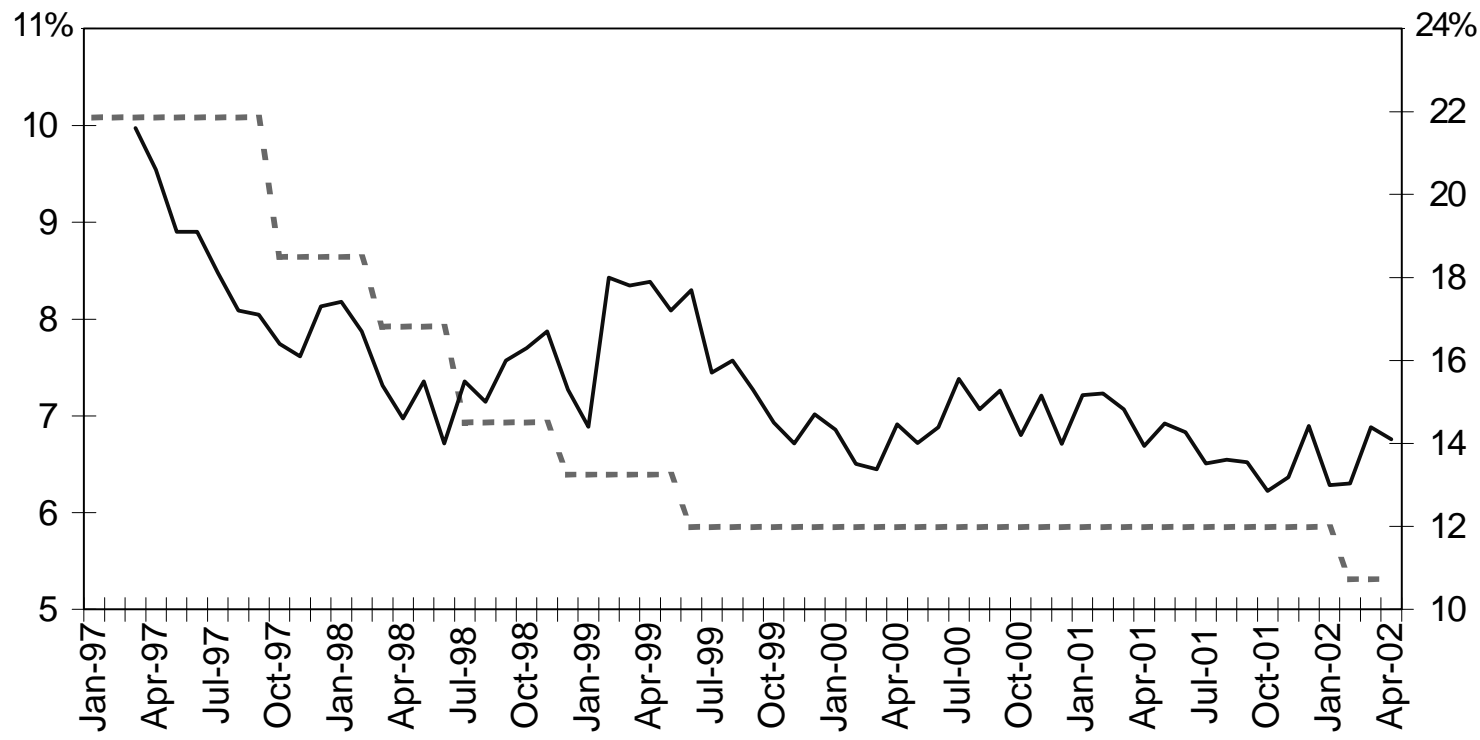

- - One-year lending rate (left axis) — Gowth of M2 (right axis)

Source: Citigroup (2002) 
Figure 7. Growth of Domestic Demand

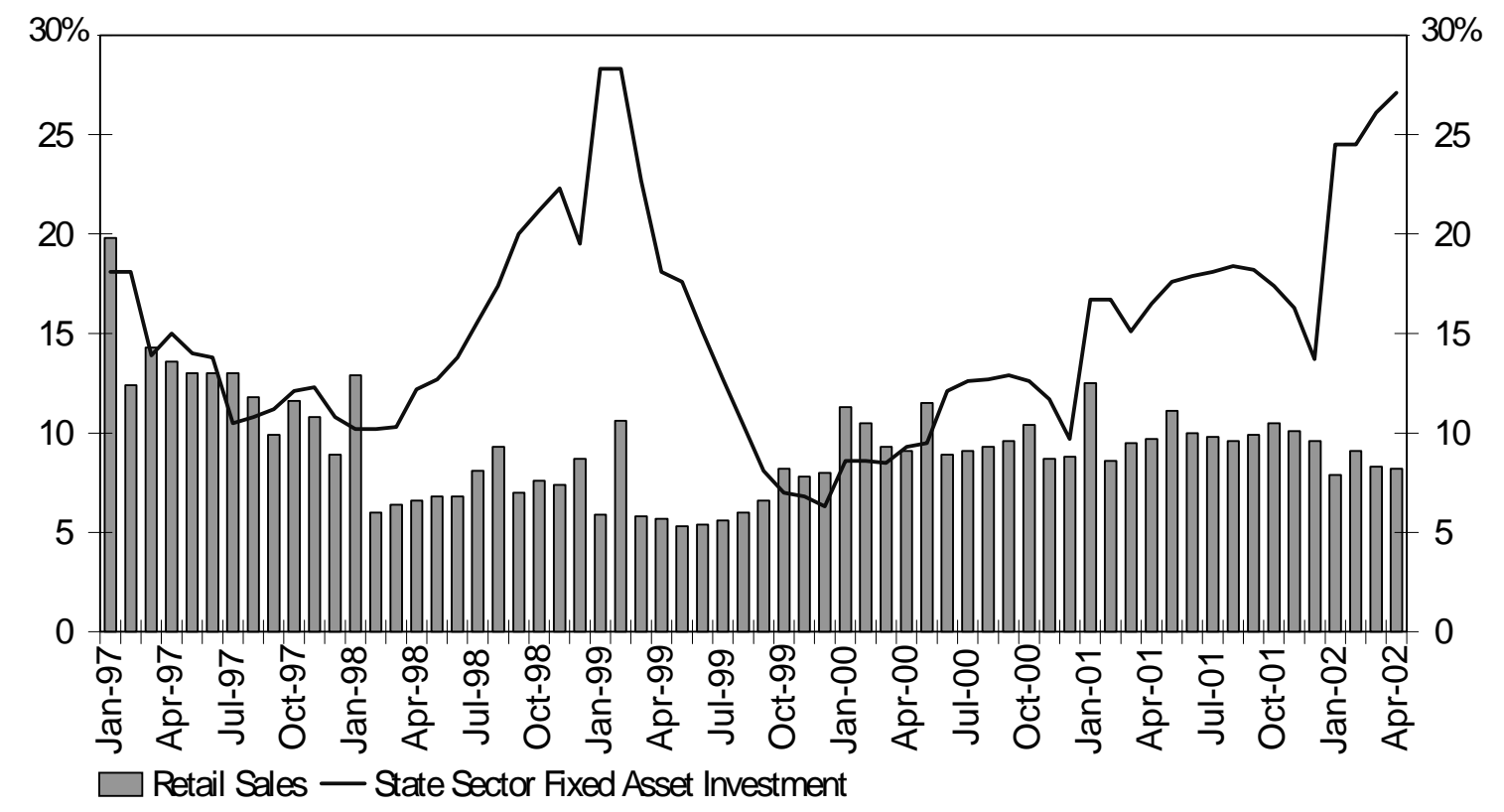

Source: Citigroup (2002).

\section{Figure 8. Growth Rates of Exports, and Foreign Direct Investment (year-over-year)}

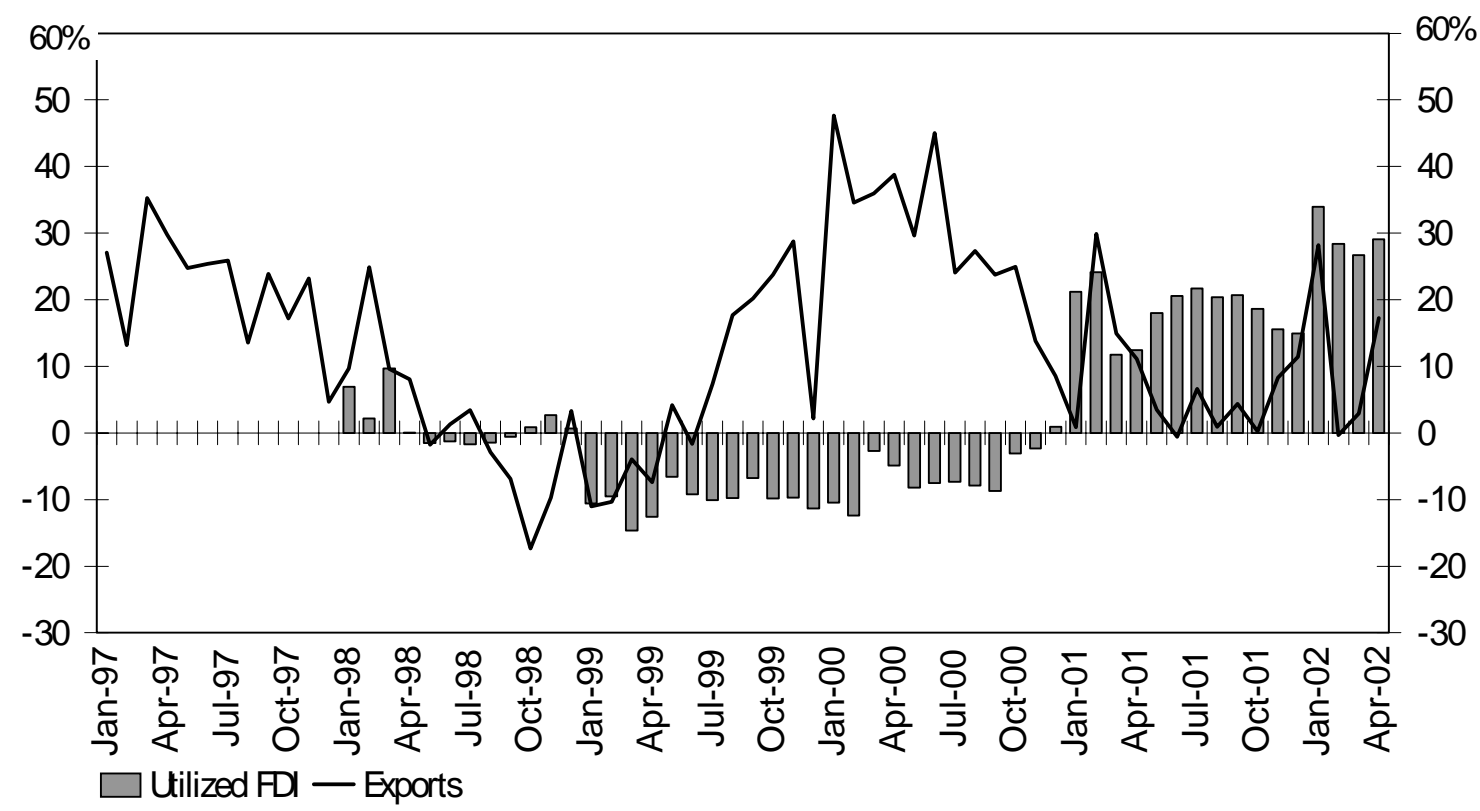

Source: Citigroup (2002). 